\title{
¿Religión sin Dios? XXI Conferencias Aranguren
}

\section{Religion without God? XXI Aranguren Lectures}

\author{
Manuel Fraijó \\ UNED, Madrid
}

\begin{abstract}
A la memoria entrañable de Quintín Racionero, amigo muy querido.
\end{abstract}

Resumen. Mientras la fe en Dios parece decaer, crece el interés por las numerosas religiones y movimientos religiosos existentes. Estamos ante un fenómeno nuevo. En el ámbito monoteísta reinaba el antiguo aserto «ningún Dios, ninguna religión». Hoy, en cambio, la religión parece caminar sola. Hay signos de que las religiones, independizadas de la antigua fe en Dios, se han establecido por cuenta propia. Hay quien piensa incluso que podrían sobrevivir a Dios.

Las Conferencias analizarán las alternancias de Dios y de la religión en el poder. Hasta bien entrada la modernidad, la religión vivió a la sombra de Dios; a partir de esa fecha, es Dios quien vive a la sombra de la religión. Las conferencias se preguntarán, además, qué clase de religión quedará en los lugares de tradición monoteísta cuando se prescinde de Dios.

Palabras clave: Religión, Dios, fe, revelación, inmortalidad, resurrección, mal, salvación, memoria, misterio, escatología, monoteísmo, ateísmo, esperanza, teología revelada, teología natural, filosofía de la religión.
Abstract. While faith in God seems to wane, interest in the many existing religions and religious movements grows. We are in front a new phenomenon. On the monotheistic field reigned the ancient assertion «no God, no religion». Today, however, religion seems to walk alone. There are signs that religions, now independent of the old faith in God, have established by themselves. There is who think religions could even survive to God.

The Conferences will discuss the alternations of God and the religion in power. Religion lived in the shadow of God until late modernity, but from that date on, it is God who lives in the shadow of religion. The lectures will also wonder what kind of religion will be in places of monotheistic tradition when God is dispensed.

Key words: Religion, God, faith, revelation, immortality, resurrection, evil, salvation, memory, mystery, eschatology, monotheism, atheism, hope, revealed theology, natural theology, philosophy of religion. 


\section{Recordando a Aranguren ${ }^{1}$}

Deseo comenzar estas «Conferencias Aranguren» agradeciendo muy cordialmente a los amigos del Instituto de Filosofía (magníficamente representado en esta mesa por Concha Roldán, su actual directora) su invitación a pronunciarlas. Mi gratitud se dirige también a Javier Muguerza por la generosa presentación que me acaba de hacer.

A nadie que conozca mi relación con Aranguren le extrañará que comience mi intervención con unas palabras sobre el gran maestro de la ética en España. Estas conferencias no son sobre él, pero casi: quiero decir que son sobre «religión», un tema al que dedicó muchas energías. Solía decir que había dedicado sus esfuerzos, por igual, a la ética y a la religión. Confesaba que algunos temas de la ética, por ejemplo el de la solidaridad, no sabía cómo abordarlos si no lo hacía desde la religión, en concreto desde la fraternidad cristiana. Aranguren fue siempre cristiano. Cristiano-católico al comienzo de su andadura filosófica, y cristiano-heterodoxo (con una heterodoxia tenue, dado que nunca practicó una disidencia dogmática fuerte) en los últimos decenios de su vida, más volcados en tareas socio-políticas. Alguna vez le escuché decir que España quizá estaba pasando de ser «de religión católica» a ser de «cultura católica». Algo que recuerda el conocido dicho de Kolakowski: "ser enteramente no cristiano significaría no pertenecer a esta cultura». No hay que olvidar que la cátedra de Aranguren, en la Universidad Complutense, era de ética y sociología. Si, durante bastantes años, se adentró en temas teológicos fue para remediar temporalmente el páramo teológico que sufríamos; de hecho, cuando consideró que en nuestra tierra habían surgido ya buenos teólogos profesionales, dejó en sus manos el menester teológico y se retiró a los cuarteles ético-políticos. Pero nunca deberíamos ol-

${ }^{1}$ Las Obras completas de Aranguren han sido publicadas por la editorial Trotta. Con motivo de su ochenta cumpleaños, J. Muguerza, F. Quesada y R. Rodríguez Aramayo editaron la obra Ética día tras día, Trotta, 1991, que recogía colaboraciones de amigos y discípulos. Por las mismas fechas, E. López-Aranguren, J. Muguerza y J. M. ${ }^{a}$ Valverde publicaron Retrato de José Luis L. Aranguren, Círculo de Lectores, 1993. Al cumplirse el centenario de su nacimiento se publicó, bajo el patrocinio de la Sociedad Estatal de Conmemoraciones Culturales/Instituto de Filosofía CCHS-CSIC, Aranguren. Filosofía en la vida y vida en la filosofía, Madrid, 2009 (editado por Ana Romero, Concha Roldán y Marta González). La editorial Trotta, en coedición con la UNED, ha publicado, en el año 2010, la obra editada por Carlos Gómez Sánchez, José Luis L. Aranguren. Filosofía y vida intelectual. Textos fundamentales. Se trata de una certera selección de textos precedida de un excelente estudio introductorio de Carlos Gómez. También Antonio G. Santesmases publicó, bajo el título José Luis L. Aranguren. La izquierda, el poder y otros ensayos, Trotta, 2005, una valiosa selección de los artículos de orientación sociopolítica, publicados durante los últimos catorce años de la vida de Aranguren y no recogidos en ningún libro posterior. También este libro va precedido de una excelente presentación del autor. Y continúa siendo fundamental la obra de Feliciano Blázquez, José Luis L. Aranguren. Medio siglo de la historia de España, Ethos, 1994. Personalmente dediqué un estudio a la figura de Aranguren en, A vueltas con la religión, Evd, Estella, 2012 pp. 387-420. 
vidar que durante algunas décadas sus servicios teológicos fueron muy considerables. Por él, por sus presentaciones de la producción teológica europea, se enteraba España del bullicioso despertar teológico que acontecía más allá de nuestras fronteras.

Pero no es este el principal aspecto que deseo destacar. Mi intención esta tarde es poner de relieve que su recuerdo continúa vivo entre nosotros. Nuestra nutrida presencia en esta sala de la Residencia de Estudiantes, un lugar emblemático al que tanto debe nuestra cultura, da testimonio de ello. En un momento clave de San Manuel Bueno, mártir, la mejor novela filosóficoteológica de Unamuno (según el mismo Unamuno), un personaje central, Lázaro, dice: «Hasta que un día hasta los muertos nos moriremos del todo». Ese día habrá llegado cuando ya nadie nos recuerde. Para el bueno de Aranguren, ese momento no ha llegado. Lo recuerdan sus hijos, sus nietos, sus discípulos, las gentes sencillas que lo paraban por la calle para saludarle o regalarle unas botellas de vino y, claro, todos nosotros.

El tema del recuerdo, de la memoria, (si me permiten una divagación) está muy presente en la historia de las religiones.

- En el cristianismo se celebra la memoria de la pasión y muerte de Jesús. Algunos teólogos actuales defienden que la forma que tiene Dios de resucitar a los muertos es "guardándolos en su memoria». No son partidarios de dar instrucciones a Dios sobre «cómo» (con cuerpo o si él) o «cuándo» (al morir o al final de los tiempos) tiene que resucitarnos. Les basta la firme confianza en que en la memoria de Dios cabemos todos.

- En algunas religiones tradicionales africanas, los antepasados son concebidos como sobrevivientes, aunque de una forma disminuida. Se continúan relacionando con sus descendientes y con Dios. Y de nuevo el tema de la memoria: mientras el difunto es recordado por su nombre - es muy importante lo del nombre- aún no está muerto del todo. Pertenece a la categoría de los «muertos vivientes». El proceso de la muerte solo se completa cuando, pasadas algunas generaciones, ya nadie recuerda al difunto. Es el momento en el que el fallecido deja de ser formalmente miembro de la familia humana. En ese instante, el muerto se une a sus antepasados y penetra en otro estado de existencia. De hecho se dice que se ha marchado «a casa». Se supone que la verdadera casa está en un más allá. Algunos pueblos acentúan la cercanía del difunto enterrándolo dentro de la casa donde vivía o en el patio de la vivienda; a veces se traslada el cadáver al lugar donde había nacido. Se indica así el lazo de unión entre el comienzo y el final, entre la protología y la escatología ${ }^{2}$.

2 J. Mbiti, Entre Dios y el tiempo. Religiones tradicionales africanas, ed. Mundo negro, Madrid 1990, pp. 35ss. 
Concluido este breve paréntesis sobre el recuerdo como forma de cariño - amar a alguien es, en palabras de G. Marcel, decirle: «tú no te me puedes morir»-, permítanme continuar rastreando en mis recuerdos sobre Aranguren. Preguntado una vez en televisión sobre cómo había discurrido su vida, Aranguren, con aire meditativo, respondió que creía no haber sido ni muy bueno ni muy malo, sino más bien regular. No sé exactamente por qué, pero me impresionó aquel «más bien regular» (y la seriedad reflexiva con la que lo pronunció). Me recordó al Platón de La República, cuando afirma que las cosas buenas de este mundo no son propiamente buenas, sino «casi buenas».

Se suele asignar a los pensadores de la Edad Media la virtud de la humilitas (humildad, sencillez, recato) y a los del Renacimiento la curiositas (afán de saber, curiosidad, indagación, búsqueda). Cabe recordar, en este contexto, el dicho de R. Lulio: «Vete por el mundo y maravíllate». Estoy seguro de que los que conocimos y quisimos a Aranguren no le negaríamos la humilitas ni la curiositas. Y tampoco le escatimaríamos el gran lema de la Edad Media: «Extensio animi ad magna» (apertura del espíritu a las cosas nobles). Aranguren cultivó este espíritu despierto, reflexivo, tenaz y vigilante («sueño de un vigilante» llamó Aristóteles a la esperanza). El tiempo de Aranguren fue, como diría Ortega, «un puro contratiempo». La guerra, su largo preámbulo y su interminable epílogo de dictadura franquista, marcó dramáticamente la vida de Aranguren. De ahí que su generación se viese obligada a hacer un notable acopio de vigor antropológico. Vigor que se manifiesta ejemplarmente en la respuesta de Bloch, coetáneo de Aranguren y víctima él también de guerras y destierros, al teólogo alemán Jürgen Moltmann cuando éste preguntó a un Bloch enfermo, cercano ya a su muerte cómo afrontaba ese último trance: «Der Tod, das auch noch!» (¡La muerte, todavía me queda esa experiencia!).

No puedo concluir esta breve evocación de Aranguren sin recordar algo muy propio de su talante: en sus libros y conferencias se hacía eco de los problemas del momento. Si hablara aquí esta tarde (él pronunció las primeras «Conferencias Aranguren»), no dejaría de mencionar a nuestros cinco millones de parados. Un sistema capitalista, de una ferocidad inhumana y pasmosa — no sé si decir desconocida hasta ahora-, nos está humillando sin miramientos ni piedad. En una reciente conferencia en Caritas de Cádiz me pidieron que eligiese yo el título, pero que en él entrase la palabra «caridad». A los comedores de Caritas, me contaban, acceden señores con corbata, pero que no levantan la mirada del suelo. Recordé una tesis doctoral de exégesis bíblica, defendida en la universidad de Tubinga, en la que se concluía que las palabras de Jesús sobre el amor no fueron «amarás a tu prójimo como a ti mismo», sino «amarás a tu prójimo, él es tú mismo».

En Cádiz pensé en lo lejos que estamos del himno revolucionario de la Ilustración, del himno de la alegría, de Schiller, al que puso música Beethoven: «Alle Menschen werden Brüder» (un día todos los seres humanos serán 
hermanos). Formamos una misma humanidad, pero sin la misma alimentación, sin las mismas medicinas, sin la misma educación, sin la misma protección jurídica, sin una vivienda de parecido confort, sin empleo... Aranguren habría denunciado (lo hizo siempre) semejante injusta y dramática situación. No habría hablado de Dios y la religión sin rodeos, sobre todo sin el rodeo de la solidaridad, tan esencial para él. De ahí que tampoco yo lamente el rodeo introductorio que acabo de ofrecerles. Ahora nos espera el tema anunciado para estas conferencias.

\section{HEGEMONÍA TEOCÉNTRICA: LA RELIGIÓN A LA SOMBRA DE DIOS}

\section{Introducción}

«Mientras más se alejan los hombres de Dios, más avanzan en el conocimiento de las religiones» ${ }^{3}$. Es posible que este aforismo de Cioran, extraño y sorprendente a primera vista, esté resultando bastante ajustado a nuestro devenir histórico. Parece que las religiones están ganando por goleada a Dios. Mientras la fe en éste decae, crece el interés — no sé si también el conocimiento, como afirma Cioran- por las religiones.

Bajo el lema «Pensar la religión», una expresión feliz que se ha ido haciendo familiar entre nosotros, van apareciendo diversos ensayos sobre la religión, en los que apenas se alude a $\operatorname{Dios}^{4}$. Algo que, hace unas décadas, tal vez no hubiera sido posible. En el Occidente monoteísta, Dios y la religión se daban la mano. Hablar de la religión implicaba referirse a Dios. Hoy, en cambio, la religión parece capaz de caminar sola. Hay signos de que ha sobrevivido a Dios. Me viene a la memoria la exclamación de H.Timm cuando terminó de leer la obra de Schleiermacher, Sobre la religión. Discursos a sus menospreciadores cultivados: «iDios ha muerto, viva la religión!» 5 . Era la religión de los románticos, entendida como «religión del corazón», como «instinto sagrado», como «experiencia interior». Eran los tiempos en los que algunos poetas exclamaban: «malditas sean las matemáticas», «maldito sea el hombre newtoniano». Solo el sentimiento recibía entusiastas parabienes. La razón se las veía y se las deseaba para ocupar su espacio.

Cabe preguntarse qué clase de religión quedará en un continente de milenaria tradición monoteísta cuando se prescinde de Dios. Y es que las religiones monoteístas apostaron siempre por lo histórico. A la literatura, por

${ }^{3}$ E. M. Cioran, Del inconveniente de haber nacido, Taurus, Madrid, 1982, p. 31.

${ }^{4}$ Véase E. Trías, Pensar la religión, Ensayos, Destino, Barcelona, 1996.

${ }_{5}$ Esta obra de Schleiermacher ha sido traducida al castellano por A. Ginzo en la editorial Tecnos, Madrid, 1990. Un excelente estudio preliminar, del mismo Ginzo, adentra en los pormenores de la obra y de la época. Tomo abundante información de este estudio. 
ejemplo, no le interesa saber si Fausto o Don Quijote son personajes históricos; pero al cristianismo le va todo en saber si existe Dios y si éste se ha revelado en la persona de Jesús. Lo mismo cabe afirmar del judaísmo y del islam. El tema se plantearía, naturalmente, de forma diferente en las religiones místicas y sapienciales, menos comprometidas con la historia. Pero intentemos alcanzar una mínima clarificación haciendo un poco de historia.

Nada invitaba a sospechar que, un día, la religión gozaría de los honores que hoy se le tributan. Ni en la Antigüedad cristiana ni en la Edad Media había espacio para una consideración autónoma de la religión. Era Dios quien se llevaba la parte del león. Se creía en él y se filosofaba sobre él. La religión no era un problema. Es más: ni siquiera era tema de reflexión. Se aceptaba confiadamente que el cristianismo era la única religión verdadera. Todavía a comienzos del siglo xx, el gran teólogo protestante A. v. Harnack afirmaba, sin rubor, que quien conoce el cristianismo conoce todas las religiones. Se trata de una afirmación claramente etnocéntrica. Por las mismas fechas, M. Müller, el iniciador de la ciencia moderna de las religiones, sostenía que quien conoce solo una religión no conoce ninguna (aludía al dicho de Goethe: quien conoce solo una lengua no conoce ninguna).

Aunque tengan un indudable aire de familia, hay grandes diferencias entre las religiones proféticas (judaísmo, cristianismo e islam), místicas (hinduismo y budismo) y sapienciales (confucionismo y taoísmo). Diferencias que persisten incluso entre las proféticas: se suele destacar la fortaleza del judaísmo en la esperanza, mientras se elogia la insistencia del cristianismo en el amor y se admira la acendrada $f e$ del islam. Son rasgos diferenciadores, aunque sea más lo que une que lo que separa.

W. James, en su libro Las variedades de la experiencia religiosa (con prólogo de Aranguren), dedica un apartado a la «Inutilidad de las definiciones sencillas de la religión» ${ }^{6}$.Y Kolakowski escribe: «Nunca estoy seguro de qué es la religión, y menos aún de qué es la filosofía, pero, sea lo que fuere, la religión incluye la historia de los dioses, de los hombres y del universo» ${ }^{7}$. No es momento de analizar el significado plural del término «religión». Su origen es cristiano y occidental. Este es el motivo de que algunas culturas lo rechacen y otras lo desconozcan. La tendencia actual entre los estudiosos es hablar de «religiones» (en plural). Creo, sin embargo, que también el singular tiene larga vida asegurada. En realidad, cada ser humano solo conoce «una» religión: la que practica o ha practicado. De las restantes solo se tienen datos, informaciones diversas; pero «poseer información» es algo bien distinto de «conocer». Conocer una religión es mirarla por dentro, familiarizarse con ella, sentir que forma parte de la propia vida. Sagazmente afirmaba

${ }^{6}$ J. James, Las variedades de la experiencia religiosa, Península, Barcelona, 1999, pp. 31 ss.

${ }^{7}$ L. Kolakowski, Si Dios no existe..., Tecnos, Madrid, 1988, p. 11. 
Renan que solo se conoce una religión cuando se la abandona. Probablemente se refería al poder cognoscitivo de la ausencia. La experiencia enseña, por ejemplo, que la ausencia definitiva de los seres queridos acrecienta su conocimiento. Es posible que la añoranza, el «echar de menos», sea mejor fuente de conocimiento que el contacto directo. Aplicado al tema que nos ocupa: el abandono de la que un día fue nuestra religión puede inquietar por dentro y conducir a conocer mejor y valorar más lo que antaño se tuvo. La religión pertenece al ámbito de lo «significativo», más que al de lo «científico». Y lo significativo siempre nos afecta y conmueve interiormente.

Entre paréntesis: más inútil aún que buscar una definición sencilla de religión sería buscarla de Dios. Etimológicamente el término deriva de la raíz «div» o «deiv» que significa brillar. Es una palabra que tiene su origen en la experiencia de la contemplación del cielo o firmamento. Expresa admiración, invocación, sobrecogimiento, dependencia, fascinación ante la realidad. Enseguida viene a la mente el «cielo estrellado» que tanto impresionaba a Kant. $\mathrm{Y}$ es imposible no recordar «el silencio de los espacios infinitos» que sobrecogía a Pascal; sin olvidar la experiencia de lo «tremendo y fascinante», de R. Otto.

Otra etimología, propia de las lenguas germánicas y anglosajonas («Gott», «God»), podría derivarse de la raíz indogermana «hu» (llamar, invocar); remitiría a la experiencia de invocar al fundamento último, al Misterio, desde una situación humana de profunda necesidad y desamparo. Siempre me impresionó la confiada proclamación de N. Söderblom: «Yo sé que mi Dios vive, lo puedo probar por la historia de las religiones». Sin embargo, algunos fenomenólogos de la religión sostienen, creo que con razón, que Dios ha llegado tarde a la historia de las religiones. La primera hora, una hora que no se sabe cuánto duró, la ocupó el «Misterio» ${ }^{8}$. Lo importante, hasta bien entrada la Modernidad, era «vivir» según las pautas de la «única religión verdadera». La Edad Media fue, como se sabe, época de angustiosa búsqueda de salvación. Todavía Lutero se lo jugará todo a la carta de un Dios «que salva». No abriga la menor duda de que existe Dios. Su atormentada pregunta será si ese Dios tendrá misericordia de nosotros. Sólo muy tardíamente se convirtió la religión en inquietante tema de reflexión. Dios, en cambio, siempre lo fue. El acceso a él discurrió por caminos de creciente complejidad. Veámoslo, aunque solo sea a grandes rasgos. Pero no perdamos el hilo de la exposición: estamos hablando de la hegemonía teocéntrica, de siglos (prácticamente hasta el Renacimiento) de predominio de la fe en el Dios cristiano. A ella seguirá, como fenómeno relativamente reciente, el auge de las religiones y el eclipse de Dios. De ahí que hayamos titulado estas conferencias

8 J. Martín Velasco, Dios en la historia de las religiones, Fundación de Santa María, Madrid, 1895, pp. 16ss. Véase también la obra, ya clásica, del mismo autor, Introducción a la fenomenología de la religión, Trotta, 2006 (7. a edición); también es excelente su estudio El fenómeno místico. Estudio comparado, Trotta, 1999. 
«¿Religión sin Dios?». El signo de interrogación pretende mitigar contundencias asertivas. El ámbito en el que nos movemos no es propicio al dogmatismo. Solo es posible hablar de prevalencias.

\section{Búsqueda inicial de Dios ${ }^{9}$}

La búsqueda inicial de Dios careció de sobresaltos. Se apelaba a la teología revelada, tan rica en datos, fechas y lugares geográficos familiares. Eran los días, ya lejanos, en los que se creía firmemente que «la Biblia tenía razón». Una interpretación literal del gran libro judeocristiano disipaba las dudas antes de que afloraran. La autoridad de la revelación, unida a otra gran autoridad, la de la inicial experiencia cristiana, situaban la existencia de Dios en un terreno libre de tormentas. El cristianismo bebió desde sus inicios en dos pozos: el testimonio y la argumentación. Hubo un fluido trasvase entre ellos. Con frecuencia, la principal argumentación en favor de la fe era el testimonio de los que la vivían y habían muerto por defenderla. Incluso en días muy cercanos a nosotros se preguntaba $\mathrm{H}$. Bergson si la acumulación y coincidencia del testimonio de los místicos no sería una certera argumentación en favor de la existencia de Dios.

Y, cuando esta ingenuidad bíblica se resquebrajó, se buscó cobijo en otra gran ingenuidad: la de la teología natural. En algún sentido era una vía de acceso a Dios más severa que la anterior. Aunque tímidamente, hacía sitio a la argumentación, a la razón. Pero se trataba de una razón coloreada de revelación. Siempre se miraba de reojo al legado bíblico. Cuando fallaban las buenas razones, se apelaba a la seguridad de la fe. La teología revelada seguía de guardia, marcando las pautas.

Todo se complicó dramáticamente cuando también la teología natural perdió su milenaria plausibilidad. Ocurrió en las agitadas fechas de la Ilustración europea. El manto protector de la revelación dejó, ahora sí, de arropar a las mentes filosóficas. Se atrevieron, como aconsejaba Kant, a pensar sin la subvención de las viejas tutelas. La autonomía del pensamiento desalojó a la ancestral heteronomía bíblico-teológica. El resto lo hicieron los sorprendentes descubrimientos de la ciencia, las convulsiones políticas, el descubrimiento de nuevos mundos y la honda transformación de las pautas morales. Dios dejó de ser un dato revelado, un dogma ciegamente aceptado. El pensar dogmático sufrió una de las mayores quiebras que ha conocido Occidente. Ni la teología revelada, ni la teología natural estaban en situación de hacer frente a los nuevos retos. Su lugar fue asumido, sin renunciar a su herencia,

9 Véase el estudio de K. Feiereis, Die Umprägung der natürlichen Theologie in Religionsphilosophie, Leipzig, 1965, pp. 6-10; J. Collins, The Emergence of Philosophy of Religion, New Haven-London, 1967; Friedo Ricken, Religionsphilosophie, W. Kohlhammer, Stuttgart, 2003. 
por la filosofía de la religión, una forma más libre y desenfadada de pensar la religión. El argumento de autoridad hizo sitio a la argumentación, a la perplejidad, a las débiles razones que sustentan la realidad del hecho religioso. Dios fue, en parte, desplazado por la religión. Lo analizaremos más adelante.

\section{De la teología revelada a la filosofia de la religión}

Durante muchos siglos, Occidente pidió prestado al cristianismo su discurso sobre Dios. Habló, pues, sobre Dios desde la teología cristiana revelada. Lo de Dios se convirtió en algo casi obvio y rutinario. Dios existía porque lo decían la Biblia y la Iglesia. Su existencia era un dato seguro. Había, ciertamente, poco espacio para la duda. Dios no era problema, sino adquisición pacífica. Se hacía filosofía desde una especie de normatividad cristiana.

El mérito, hay que decirlo, fue del cristianismo. En su andadura inicial, el cristianismo optó por el Dios de los filósofos. Preguntados por la identidad de su Dios, los cristianos no lo relacionaron con Zeus, Hermes, Dionisos o algún otro dios del panteón grecorromano. Pablo se atrevió a vincularlo con el Dios del que hablaban los sabios atenienses (Hch 17,28). La naciente nueva religión trazó así una línea divisoria entre ella y los cultos ya establecidos. Insistió en que, cuando ella decía «Dios», se estaba refiriendo al ser mismo, a lo que los filósofos llamaban el fundamento de todo ser. De hecho, los nombres bíblicos de Dios - Padre, Señor, Salvador- cedieron su puesto a la nomenclatura filosófica: Infinito, Necesario y, a partir del Cusano, lo Absoluto.

Vale la pena, a estas alturas de nuestra exposición, dedicar unas líneas al Cusano, dado que encarna ejemplarmente algunos de los avatares que venimos narrando. Casi un siglo antes de Lutero, Nicolás de Cusa, el hombre puente entre la Edad Media - la noción de Edad Media aparece por primera vez en el elogio fúnebre del Cusano, escrito por uno de sus secretarios italianos - y el Renacimiento, el pensador que unió amablemente toda la humilitas de la Edad Media con la curiositas del Renacimiento, consideró «impertinente» plantearse la pregunta por la existencia de Dios. Para el Cusano, Dios era evidente, no necesitaba demostración. El problema será cómo conocerle. Nicolás de Cusa se refugió en la teología negativa del Maestro Eckhart y dedicó una trilogía al tema del conocimiento de Dios. El primer opúsculo se titulaba De Deo abscondito (sobre el ocultamiento de Dios). En él se destaca la absoluta trascendencia divina. Un año después, en 1445, escribió el segundo volumen: De quaerendo Deo (sobre la búsqueda de Dios). Precisamente porque es trascendente hay que buscarlo siempre y, según el Cusano, solo se le encuentra en el cristianismo. De ahí el título del tercer volumen: De filiatione Dei (sobre la filiación divina). El cristianismo 
nos declara hijos de Dios. Pero sobre Dios solo poseemos una docta ignorantia. Conocer es comparar diversas magnitudes, pero ¿con quién compararemos a Dios si nos es desconocido? Solo sabemos que es la coincidentia oppositorum (la coincidencia de los contrarios).

El Cusano afirma que, mientras viajaba de Constantinopla al Concilio de Florencia, en 1437, al contemplar la inmensidad del mar recibió «como un regalo de arriba, del Padre de las luces, la visión de la coincidencia de los contrarios en el infinito». Esta visión es la que dio lugar a su primera y más importante obra filosófica: De docta ignorantia (la mejor definición de la ciencia desde Platón, según Ortega, para quien el Cusano es la única figura genial del siglo Xv). Sobre Dios, se mantiene en ella, solo se pueden afirmar generalidades, por ejemplo, que es el máximo y el mínimo, que en él coinciden posibilidad y actualidad, es decir, que Dios es todo lo que puede ser. Es lo que expresó en su escrito De possest. O que Dios es «lo no otro», como pone de manifiesto en De non aliud (sobre lo no otro), redactado en 1462, muy cercano ya a su muerte, donde vuelve a destacar la absoluta trascendencia de Dios. Todo su pensamiento se podría resumir en su fórmula preferida: «quia ignoro, adoro». Con ella, su autor se inscribe dentro de una tradición que acepta con humildad el sacrificium intellectus cuando está en juego el conocimiento de Dios. Una tradición sobre la que habrá que reflexionar en el futuro. Es incluso posible que su aplicación desborde el ámbito filosóficoteológico y se convierta en una especie de aval para la supervivencia de la humanidad. También la razón puede morir de éxito, víctima de sus descomunales logros científico-técnicos.

La opción cristiana por el Dios de los filósofos, practicada por Nicolás de Cusa y tantos otros pensadores cristianos, fue de incalculables consecuencias. Con ella, el cristianismo se arrimó más al logos que al mito, iniciando así un poderoso proceso de desmitologización. Pudo hacerlo porque, desde Jenófanes hasta Platón, los mitos habían sido ya zarandeados. Platón intentó reemplazar el clásico concepto homérico de mito por otro más acorde con el logos.

Esta opción por la filosofía fue ampliamente recompensada: la filosofía aceptó la matriz cristiana y, durante siglos, se filosofó desde la teología revelada. Sería muy complicado separar lo cristiano de lo filosófico en la larga lista de los filósofos occidentales. Obviamente, mientras duró esta situación, no hubo espacio alguno para un discurso inseguro, problemático sobre Dios. La teología revelada cercenaba esta posibilidad.

Las aguas se agitaron un poco cuando la teología revelada tuvo que hacer sitio a la teología natural. La situación se volvió más precaria. El punto de partida no era ya la fe ni la autoridad de la Biblia, sino las posibilidades del conocimiento humano. Aunque tímidamente, se comenzó a hacer un hueco a la razón. La Biblia dejó de ser el único oráculo. Para acceder a Dios, 
por ejemplo, se comenzó a partir de lo visible y experimentable. Es el caso de las cinco vías de santo Tomás.

El talante de la teología natural fue siempre más modesto que el de la teología revelada. Sobrevino, además, algo que le complicó la existencia: el siglo XVII desarrolló una gran sensibilidad filosófica ante el problema del mal. Leibniz acuñó el término "teodicea» que quedó englobado dentro de la teología natural. La nueva tarea supuso una notable sobrecarga. No era, no es, fácil justificar a Dios frente al problema del mal.

Pero las responsabilidades de la teología natural nunca fueron agobiantes, ya que nunca trabajó en solitario. Siempre podía contar con la buena disposición de la teología revelada para echarle una mano. En realidad, nunca hubo separación estricta entre ambas. Se puede incluso afirmar que la teología natural ha vivido tutelada por la teología revelada. El final de esa tutela, la conquista de su autonomía e independencia, supuso un arduo y laborioso proceso. Y, cuando dicho proceso culminó, era ya tarde para disfrutarlo. A partir de la segunda mitad del siglo XVII y, sobre todo, durante todo el XVIII, las seguridades que ofrecía la teología natural sufrieron un profundo rechazo. Nació una forma más problemática de gestionar el tema religioso, de la que ya no podía hacerse cargo la pacífica, segura y bien intencionada teología natural. Fue entonces cuando tomó el relevo la filosofía de la religión.

La teología natural fracasó precisamente cuando Dios dejó de ser tema para convertirse en problema. Es el momento en el que la Ilustración europea, con Kant a la cabeza, vuelve la espalda a las tradicionales pruebas de la existencia de Dios. Es significativo: Dios dispuso de pruebas de su existencia mientras no las necesitó, mientras Europa fue cristiana; en cambio, cuando Dios entró en crisis, cesó el ajetreo de las pruebas. Enseguida se percibió - Hegel también - que las pruebas, en las que tanto insistía la teología natural, en lugar de asegurar la existencia de Dios, solo mostraban la finitud y contingencia del hombre y del mundo. Pero, de ninguna forma eran la respuesta a dicha finitud y contingencia.

La misión de las pruebas pasó a ser la de poner de manifiesto que es necesario ir más allá del hombre y del mundo si se aspira a lograr un fundamento sólido para la realidad. Es el sentido que les otorgó Hegel. Él era consciente de que se trataba de un proceder ilegítimo, ya que, partiendo de la realidad finita se pasa a afirmar la existencia de Dios, que pertenece a otro orden de realidad. A pesar de todo, Hegel las mantuvo como expresión formal de que el hombre supera lo finito. Precisamente porque era consciente de que no es legítimo hacer depender la existencia de Dios de la realidad finita, renovó el argumento ontológico y lo defendió frente a la crítica kantiana. La gran ventaja de este argumento radica precisamente en que su punto de partida no es la finitud, sino el concepto de Dios.

Las pruebas de la existencia de Dios no demuestran, pues, que exista Dios, sino, a lo sumo, que el hombre lo necesita radicalmente. Éste es, tam- 
bién, el sentido que les otorga la teología actual. Uno de sus máximos representantes, el malogrado D. Bonhoeffer, fue duro con ellas: «Einen Gott den es gibt, gibt es nicht». Traducido libremente: un Dios cuya existencia fuese constatable no sería realmente Dios. Y un teólogo tan ávido de fundamentos como W. Pannenberg escribió: «Un Dios cuya existencia pudiese ser demostrada mientras el mundo va de mal en peor y los sufrimientos de los hombres claman al cielo, no sería la solución del oscuro enigma de nuestra vida» ${ }^{10}$.

El fracaso de la teología natural y de su principal baluarte, las pruebas de la existencia de Dios, puso radicalmente de manifiesto el carácter problemático de la realidad de Dios. En los últimos tres siglos, Dios - si es permitido hablar así- ha vivido en un permanente sobresalto. Filósofos, e incluso algunos teólogos, amontonaron signos de interrogación sobre su existencia. Ante tan alarmante situación, la teología natural cedió el testigo a la filosofía de la religión. A partir del siglo XVIII será ella quien deberá gestionar los intereses de un Dios en apuros. Pero conviene hacer una precisión importante: Dios no se convirtió en problema por obra y gracia de la filosofía de la religión; las cosas sucedieron a la inversa: porque Dios era pensado y vivido como problema, como algo inseguro, nació la filosofía de la religión.

Es más: la filosofía de la religión es el resultado de un cansancio. La época - Hegel insiste en ello - se había cansado de especular sobre Dios y sus pruebas. La atención se centraba ahora en el otro polo de la relación religiosa: en el hombre. El giro antropológico, lentamente preparado por Lessing, Herder, Hamann y, antes aún, por Nicolás de Cusa, comenzó a dar sus frutos. Este último, el Cusano, se atrevió a hablar del hombre como «humanus Deus», «secundus Deus», «infinito relativo» frente al infinito absoluto que es Dios. Llegó incluso a escribir: «Dios es el monedero que acuña las monedas, pero el hombre es el banquero que determina su valor». La antropologización de la pregunta por Dios estaba, pues, en marcha. Ya no se partirá, para acceder a Dios, del cosmos, sino del hombre. Kant, con su énfasis en la subjetividad humana, hizo el resto.

Se llegó incluso a dudar de si Dios tenía cabida en la filosofía de la religión. Hubo quien defendió que ésta debía centrarse exclusivamente en el hombre. La moción no prosperó. Es sabido que los grandes iniciadores de la filosofía de la religión - Hume, Kant, Hegel - continuaron filosofando sobre Dios (Hume y Kant), o incluso desde Dios (Hegel). Ni siquiera los grandes críticos de la religión - Feuerbach, Marx, Nietzsche, Freud- prescindieron del tema «Dios».

La filosofía de la religión se decidió a ser generosa con su temario. Consideró que no debía vincular su identidad a un catálogo de temas sino a un

${ }^{10}$ W. Pannenberg, «Wie kann heute glaubwürdig von Gott geredet werden?», en F. Lorenz (ed.), Gottesfrage heute, Stuttgart, 1969, p. 52. 
estilo de filosofar: estilo que debía ser crítico, riguroso, abierto, libre y, por supuesto, «filosófico». La filosofía de la religión es, ante todo «filosofía». Hegel la vinculó con la «lucidez» y la liberó de cualquier tarea misionera: la filosofía de la religión no se preocupa de convertir a nadie, sino de que los seres humanos nos aproximemos al hecho religioso desde la lucidez. Lucidez que impedirá fanatismos, intolerancia y fundamentalismos de cualquier género. La razón, la filosofía, sostiene Horkheimer, se ocupa de que «no nos timen». La historia enseña que los timos en el ámbito de las religiones han sido especialmente trágicos y virulentos.

En cuanto «tema», Dios tiene, pues, cabida en la filosofía de la religión. Pero, en cuanto «Dios», sólo se le admite como «problema». En ningún caso se le permite la entrada como «dato revelado» (teología revelada), ni como «dato seguro» (teología natural). Es más: estas exigencias son compartidas por la teología crítica de nuestros días. También ella rechaza lo que se ha llamado una teología posicional (G. Sauter), es decir, una teología bien asentada que amontona enunciados sin preocuparse de justificar su interna plausibilidad. En su lugar, el mismo G. Sauter, defiende una teología argumentativa que procura razonar sus contenidos ${ }^{11}$. Lo que ocurre es que, en teología, tales declaraciones de intenciones suelen ir seguidas de un cierto laxismo.

Concluyo aquí este recorrido por las formas teóricas globales de abordar la existencia de Dios. Dios comenzó con todo a su favor y los avatares de la historia le han ido - usemos un símil futbolístico- achicando espacios. El discurso seguro y dogmático de la teología revelada ha desembocado, pasando por el noble, aunque infructuoso esfuerzo argumentativo de la teología natural, en una nueva figura conceptual: la filosofía de la religión. Desde ella, lo de Dios queda en problema y pregunta abierta.

\section{Una fugaz mirada al presente}

Tan abierta que algunos pensadores de nuestros días practican su negación decidida y serena, sin «agonías» unamunianas ni quiebras existenciales. En el siglo XXI Dios no es un dato seguro. No lo es para la filosofía, ni lo es para las sociedades secularizadas de nuestros días. Desde Kant, la referencia a Dios no viene precedida de un «yo sé», sino de un «yo quisiera». Todos recordamos su lapidario: «Debí suprimir el saber para hacer lugar a la fe». Dios, en el mejor de los casos, es un postulado, un anhelo, la condición de posibilidad para evitar la fatal quiebra que supondría para los humanos el desembarco final en la nada que tanto torturaba a Unamuno; no se resignaba

${ }^{11}$ Véase G. Sauter, Zukunft und Verheissung, Theologischer Verlag Zürich, 1973, 2. ${ }^{\text {e ed. }}$ 
a que «nuestro trabajado linaje humano» se reduzca a «una fatídica procesión de fantasmas que van de la nada a la nada».

Pero lo cierto es que, deseos aparte, nada ni nadie puede asegurar que exista Dios. Dios carece ya de detractores empedernidos y de defensores acalorados. Su hegemonía de antaño ha entrado en declive. Tan ocioso sería aplicar el verbo «demostrar» a su existencia como a su no-existencia. Se ha hecho un gran silencio en torno a él. Es lo que aconsejó Heidegger: silenciar el tema Dios en el ámbito del pensamiento. Es más: consideró «más aconsejable renunciar no solo a la respuesta, sino a la pregunta misma (por Dios) $\gg{ }^{12}$. Pero ya antes de Heidegger sabíamos que la mayoría de las más acendradas búsquedas de Dios desembocaron en el apofatismo, en el silencio. De nuevo Heidegger: «honramos a la teología en cuanto callamos acerca de ella» ${ }^{13}$. Es comprensible que Dios corra el mismo destino que la teología.

Heidegger había afirmado que su filosofía era «un estar a la espera de Dios». La frase es de 1948, pero la repitió en 1966 en la conocida entrevista publicada por el semanario alemán Der Spiegel bajo el título «Ya solo un Dios puede salvarnos». En ella sostiene que no podemos atraernos a Dios «pensándolo». A lo sumo "podemos estar a la espera». Solo es posible un sich-offen-halten (un mantenerse abierto) para el advenimiento o la ausencia de Dios. La espera es el temple del pensar que se dispone a contar con Dios. Al esperar dejamos abierto aquello que esperamos. Esperar es introducirse en el ámbito de lo abierto, de lo lejano y oculto.

En diálogo con E. Fink, Heidegger contrapuso la espera a la esperanza. La esperanza cuenta con algo, se ocupa en firme de algo; la espera consiste en conformidad, recato y discreción; la esperanza incluye un momento de agresividad, la espera de contención. Heidegger elogia la espera en un tiempo que, según él, no sabe esperar. Empeñarse en obligar a Dios a salir de su silencio puede resultar inoportuno. Todo tiempo humano es esencialmente tiempo de espera, algo que implica aprender a vivir en estado de inseguridad. La edad del silencio de Dios es época de renuncia, pobreza y sacrificio, incluido el sacrificium intellectus. Renuncia, pobreza y sacrificio acompañan a la revelación del ser. Y la revelación del ser es requisito para la revelación de Dios. (Was ist Metaphysik, 49-50) ${ }^{14}$.

${ }_{12}$ M. Heidegger, «Zeit und Sein», en Zur Sache des Denkens, Max Niemeyer, Tübingen, 1969, pp. 1-25, cita, p. 21.

${ }_{13}$ Tomo esta cita de R. Safranski, Un maestro de Alemania. Martin Heidegger y su tiempo, Tusquet, Barcelona, 1977, p. 167.

${ }_{14}$ «Soy un teólogo cristiano», escribió Heidegger, en 1920, a K. Löwith. En 1935, cuando ya Heidegger no hubiera repetido semejante autopresentación, volvió, sin embargo, a escribir: «Sin... mi ascendencia teológica jamás hubiera yo llegado al camino del pensamiento. Pero la ascendencia nunca deja de ser futuro». Dos citas «llamativas» en una filosofía que se prohibió a sí misma tanto el teísmo como el ateísmo. (Las citas se encuentran en las pp. 678 y 679, respectivamente, de H. Küng, ¿Existe Dios?, Cristiandad, Madrid, 1979). 
Dios está, pues, conociendo tiempos de silencio. La filosofía calla sobre él. Desde que murieron sus grandes críticos del siglo XIX y comienzos del Xx -Feuerbach, Marx, Nietzsche, Freud - Dios no viene siendo molestado ni requerido por los filósofos. Existen, por supuesto, excepciones, pero se trata de excepciones que solo ofrecieron «discursos interrumpidos», titubeantes e inseguros sobre él. Fue el caso de Benjamin, Horkheimer, Adorno, Bloch, Wittgenstein, e incluso Heidegger. Todos ellos renunciaron al discurso lineal, seguro, y bien trabado de las épocas precedentes. En casi todos ellos prevalece el aforismo fugaz sobre el tratado compacto y ambicioso.

En los últimos tiempos, sin embargo, los «discursos interrumpidos» sobre Dios están siendo remplazados por los «discursos compactos» que, con total desenfado y aplomo asertivo, niegan su existencia. Solo puedo mencionar a unos cuantos protagonistas.

Es el caso, por ejemplo, de Marcel Gauchet. Acepta un «absoluto», pero «terrenal»: «Lo absoluto es humano, no demasiado humano, pero nada más que humano: dejando completamente de mirarnos en el espejo de Dios, podemos ver al fin al hombre» ${ }^{15}$. Eso sí: «El ser humano puede ser o no ser religioso, pero no puede dar de lado a lo inmaterial». Se rechaza la idea de Dios, pero se reclama, con razón, lo inmaterial, lo espiritual, lo inefable. Es lo que hizo entre nosotros Tierno Galván: el teísmo no debe proclamarse depositario único del misterio y de la espiritualidad; sin él sigue habiendo poesía, música e incluso mística, mística profana.

En parecida línea se mueve el libro de Michel Onfray ${ }^{16}$. Solo a través de una «descristianización radical de la sociedad, afirma, se puede alcanzar nuestro único bien verdadero: la vida terrena». Solo existe una trinidad: «hombre, materia y razón». La meta es «deconstruir los monoteísmos y desmontar las teocracias». Estamos ante una polémica y apasionada defensa del ateísmo y del hedonismo ético.

También R. Dawkins ${ }^{17}$ se apunta a la deconstrucción más severa. Su libro El espejismo de Dios desea mostrar: 1. La irracionalidad de la creencia en Dios, 2. El daño hecho por la religión a la sociedad desde las cruzadas al 11 de septiembre, 3. Lo feliz que puede ser el ateo. Dawkins proclama, con ardiente celo misionero, las ventajas y orgullo de ser ateo.

Esta severidad atea es defendida también por Paolo Flores D'Arcais. Su tesis es que después de Kant, Hume, y Freud «estamos en condiciones de afirmar abiertamente, y razonablemente, la NO existencia de Dios y de la inmortalidad del alma. Sabemos quiénes somos: unos simios apenas modificados, aunque este «apenas» (un porcentaje irrisorio del ADN) haya abierto al animal-hombre posibilidades impresionantes». $\mathrm{Y}$ añade: "Y sabemos a p. xii.

${ }^{15}$ L. Ferry y M. Gauchet, Lo religioso después de la religión, Anthropos, Madrid, 2007,

${ }_{16}$ Michel Onfray, Tratado de ateología, Anagrama, 2008.

17 R. Dawkins, El espejismo de Dios, Espasa, 2007. 
dónde vamos: a ninguna parte...» ${ }^{18}$. No puedo evitar recordar que, cuando E. Bloch se preguntaba «a dónde vamos», respondía, con invariable tozudez antropológica: «siempre a casa». Para Bloch, tan ateo como Flores D'Arcais, esa «casa» no era, ciertamente, el «cielo» cristiano, pero tampoco era «ninguna parte». En realidad, no sé qué era, y creo que Bloch tampoco lo sabía. Tal vez se trataba solo de un guiño, pero de un exigente guiño, al dinamismo postulatorio kantiano. El kantiano practicante que fue Bloch no se resignaba a que, al final de los finales, nos quedemos «sin casa». Sería, para expresarlo en términos tristemente actuales, un desahucio doloroso e injusto. Bloch, como Kant, Unamuno, y tantos otros, rechaza la «nada» como morada final; todos ellos consideraban que los seres humanos, a pesar de nuestro tantas veces deplorable historial moral, merecemos algo mejor. Bloch se resistía, «por dignidad personal», a «acabar como el ganado». Eso sí: Bloch distinguía, aunque no implacablemente, entre las «exigencias» (das verlangte) y los «logros» objetivos (das erlangte). Los seres humanos hemos sabido desde siempre que nunca coincide lo anhelado con lo realmente conseguido.

Tal vez por avatares de este género concluye Vattimo que «Dios sigue en circulación» ${ }^{19}$. Su postura es bien diferente de la de su paisano Flores D’Arcais. Expresamente, en diálogo con R. Rorty, afirma: «Yo me profeso creyente, pero creyente en el Dios de la Biblia. La Biblia es la base de una tradición a la que pertenezco, y sin la cual no puedo pensarme» ${ }^{20}$. Quiere creer en un Dios como creyeron Leibniz, Descartes, Kant, Voltaire, Rousseau, y tantos otros. Y también desea creer en la inmortalidad, entendida ésta como «capacidad de transmisión "espiritual", de diálogo entre épocas y generaciones, asegurado por la cultura...»" ${ }^{21}$. Desea que resucite incluso su gato: «pobre de mi gato; confío en que resucite en mí.... ${ }^{22}$. Vattimo recuerda que una parte importante del PIB está ligada al culto a los muertos, a la esperanza en la supervivencia. En realidad, Vattimo nos recuerda un dato que ya nos ha salido al encuentro: que al menos culturalmente somos cristianos (Kolakowski).

Deseo concluir este apartado con un relato que me resulta especialmente emotivo. Me refiero a H. Jonas, filósofo de la religión judío, cuya madre fue sacrificada en Auschwitz en 1942. En su libro Pensar sobre Dios y otros ensayos, sostiene que cuando se trata de Dios «el voto de los felices se puede dejar de lado, mientras que el de los que sufrieron, el de los infelices,

${ }^{18}$ P. Flores D'Arcais, M. Onfray y G. Vattimo (eds.) Ateos o creyentes, Paidós, Barcelona, 2009, p. 14.

19 R. Rorty/ G. Vattimo, El futuro de la religión, Paidós, Barcelona, 2006, p. 124.

${ }^{20}$ P. Flores D'Arcais, M. Onfray, G. Vattimo (eds.), Ateos o creyentes, Paidós, Barcelona, 2009, p. 20.

${ }^{21}$ Ibid., p. 21.

22 Ibid. 
cuenta doblemente en su peso y validez» ${ }^{23}$. Una tesis algo diferente de la defendida por J. Stuart Mill en su libro, La utilidad de la religión: «Son precisamente los que nunca han sido felices los que tienen este deseo (el de perdurar en otra vida después de ésta). Quienes han poseído la felicidad pueden soportar la idea de dejar de existir; pero tiene que ser duro morir para quien jamás ha vivido» ${ }^{24}$. Y ese es precisamente el problema de Jonas: los que nunca disfrutaron de una vida elementalmente lograda. Por eso propone «escuchar la opinión de las víctimas de la miseria, la opinión de los menos sobornados por las alegrías gozadas» ${ }^{25}$. La obra de H. Jonas es todo un alegato en favor de la normatividad de las víctimas de Auschwitz. Una normatividad que alcanza también tintes dramáticos en el crudo dilema propuesto por Benjamin y Horkheimer: si se mantiene vivo el recuerdo de las incontables generaciones de seres humanos sacrificadas a lo largo y ancho de la historia universal, es imposible saborear la propia felicidad; como solución cabe recurrir al olvido, pero una felicidad lograda a golpe de olvido ies humana? Por tanto: si se recuerda, es imposible ser feliz; y, si se olvida, se alcanzará la felicidad, pero a costa de prescindir de la solidaridad. Personalmente nunca supe cómo escapar a este dilema, a no ser, claro está, que se acepte, con la seguridad sin garantías propia de la fe, la prometida restauración cristiana universal, en virtud de la cual quedará definitivamente implan-

${ }^{23}$ H. Jonas, Pensar sobre Dios y otros ensayos, Herder, Barcelona, 1998, p. 99.

24 J. Stuart Mill, La utilidad de la religión, Alianza, Madrid, 1986, p. 91.

${ }^{25}$ H. Jonas, op.cit.,p. 99. Vengo manteniendo un prolongado diálogo con Javier Muguerza sobre el tema de las víctimas, de los que «en esta vida» no encontraron la felicidad, la salvación. Muguerza piensa que la salvación, si la hay, es obligado buscarla «irremisiblemente en esta vida», sin confiar en futuros consuelos escatológicos. Sin embargo, mi problema, como el de Jonas, son precisamente los que «en esta vida» no encontraron salvación. Para ellos me atrevo, desde el dinamismo postulatorio kantiano, a mantener «la débil esperanza mesiánica» (W. Benjamin) de que sean revisadas sus causas y conozcan un futuro «sanado» en el que se les haga justicia. Salta a la vista la indefensión de esta esperanza. Está llena de supuestos inverificables. El primer supuesto es el de la existencia de Dios. No en vano Kant agregó el postulado de la existencia de Dios al de la inmortalidad del alma como su condición de posibilidad. Consuela pensar, como K. Löwith, que es un privilegio de la filosofía y de la teología plantear preguntas que carecen de respuesta empírica. Preguntas a las que Muguerza, desde su reconocida increencia, también se muestra altamente sensible. Nuestra diferencia tal vez no resida en la respuesta (es posible, pero no estoy seguro de ello, que ambos aceptásemos los «puntos suspensivos» bajo los que Aranguren sitúa toda apelación a la escatología), sino en la mayor obstinación, más teológica que filosófica, con la que yo planteo la pregunta. Pero, si «el creyente heterodoxo» que fue Aranguren dejaba en puntos suspensivos el pilar central de la fe, la resurrección, tal vez sea también posible la existencia de «increyentes heterodoxos», que no se cierren por completo a la extraña y remota posibilidad de una salvación final, de «otra vida». Pero es probable que Muguerza piense que estoy llevando el irenismo demasiado lejos, en pos de una imposible coincidentia oppositorum. Ya lo dirá... Véase J. Muguerza, «Una visión del cristianismo desde la increencia», en J. Muguerza y J. A. Estrada, Creencia e increencia: un debate en la frontera, Sal Terrae, Santander, 2000. Mi diálogo con Muguerza puede verse en mi libro, Dios, el mal y otros ensayos, Trotta, Madrid, 2006. 
tada la justicia que las víctimas de la historia no experimentaron. No parece que haya otra salida.

Es especialmente conmovedor el relato de H. Jonas sobre su encuentro con H. Arendt. Cuenta que Arendt le desafió con la siguiente pregunta: «¿Cree usted en Dios? Tan directamente nadie me lo había planteado. ¡Y una persona casi desconocida! Primero la miré algo desconcertado, pero entonces lo medité y dije - para mi propia sorpresa - "Sí". Hannah se estremeció, todavía recuerdo que casi me miró espantada. “¿De verdad?” Y contesté: “Sí, en definitiva, sí. Más allá de lo que eso pueda significar, creo que la respuesta "sí" se ajusta más a la verdad que un "no". Poco después, a solas con Hannah, volvimos a hablar de Dios, y ella me dijo: "Nunca he dudado de la existencia de un Dios personal". A lo que le dije: "Pero Hannah ¡nunca lo hubiera imaginado! Y ahora sí que no entiendo por qué te quedaste tan extrañada la otra noche". Y ella contestó: "Estaba conmovida por el hecho de escucharlo de tus labios, pues jamás lo hubiera imaginado". De manera que ambos nos habíamos sorprendido mutuamente con aquella confesión» ${ }^{26}$.

¿Qué ha pasado para que la fe en Dios, tan acendrada durante siglos, conozca los eclipses que hoy conoce? Aventuramos solo dos razones, aunque obviamente son muchas más.

\section{Razones para el cambio \\ a) Un curriculum precario}

Escasean los datos sobre Dios. Al mismo tiempo crece la exigencia de información. Después de la Ilustración, se desea saber en qué se cree. «Atrévete a saber», exhortó Kant. Sin embargo, acerca de Dios hay poco que saber. Hace años, escribió A. Fierro: «Acerca de Dios se carece de noticias absolutamente fidedignas; sólo se cuentan historias que permiten formarse ciertas conjeturas ${ }^{27}$. Así es. Si uno se asoma a los grandes diccionarios de teología o filosofía se topa con un extenso curriculum divino; pero se trata de un curriculum de autoría humana. La historia de Dios es el gran relato de las percepciones que los seres humanos hicieron de él. Dios mismo, sin embargo, guarda silencio. Él no llega nunca directamente al receptor.

Es verdad que las religiones monoteístas hablan de la «revelación» de su Dios. Y K. Barth insistió — antes lo había hecho Hegel — en que la revelación es «automanifestación» de Dios. Pero tal automanifestación nunca es directa.

${ }^{26}$ H. Jonas, Memorias, Losada, Madrid, 2005, p. 370.

27 A. Fierro, Historias de Dios, Laia, Barcelona, 1981, p. 8. De la amplia y polifacética obra de A. Fierro véase su libro, Sobre la religión. Descripción y teoría. Taurus, 1979. Su última obra, de gran interés, se titula, Después de Cristo, Trotta, 2012. Me ocupé de A. Fierro

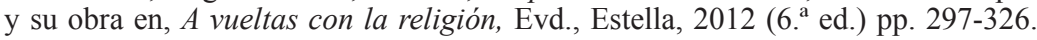


El verbo «revelar» nunca tiene, en el Nuevo Testamento, a Dios como complemento directo. Eso queda para la gnosis. El Dios cristiano sólo revela «algo» de sí mismo: su amor, su ira, su misericordia, su justicia. Pero nunca se revela a sí mismo.

Incluso un teólogo tan teocéntrico como W. Pannenberg ha escrito: «Según los testimonios bíblicos, la autorevelación de Dios no se ha realizado de una forma directa, algo así como en la forma de una teofanía, sino indirectamente, a través de las obras de Dios en la historia $\rangle^{28}$. Somos, pues, invitados a detectar las obras de Dios en la historia. Una tarea a todas luces ardua. Habría que ser muy «lanzado» para atreverse a asignar a Dios determinados acontecimientos intrahistóricos y sustraerle otros. ¿Con qué criterio? Pannenberg se atrevió a ofrecer el siguiente: «En el momento en que un acontecimiento nos ilumina la realidad total en la que vivimos y estamos interesados, en ese momento, tal acontecimiento nos revela la actuación de Dios» ${ }^{29}$. Dios queda vinculado a la Erhellungserfahrung, que Pannenberg asumió de su maestro en filosofía, K. Jaspers. Somos, pues, remitidos a la «experiencia de iluminación». Iluminar significa, en Jaspers, «dar sentido». Pero identificar la acción de Dios con la experiencia de sentido parece excesivamente generoso. Le concede a Dios todas las ventajas. Y deja abiertos muchos interrogantes. El más crucial de todos ellos sería éste: ¿qué hacemos con el sinsentido? ¿No tiene Dios nada que ver con él? Bíblicamente, Dios es el Señor de toda la realidad. ¿Con qué derecho le sustraemos el lado oscuro de las cosas? ¿Qué hacemos con el mal? ¿Es obligatorio sustraer a Dios esa amarga parcela de la realidad?

Además, la automanifestación indirecta de Dios en la historia tropieza con otra dificultad: la historia no ha llegado a su final. Dilthey lo formuló con precisión: «habría que esperar al final de la historia para poseer todo el material que permita pronunciarse sobre su significado ${ }^{30}$. Y, convencido de que nadie conoce el final de la historia, Dilthey sacó la resignada conclusión de que no son posibles pronunciamientos definitivos. Solo tenemos acceso a verdades parciales y relativas. «El todo, insiste Dilthey, solo se nos hace presente en la medida en que las partes lo hacen comprensible» ${ }^{31}$. A su vez, las partes sin el todo permanecen mudas. No hay, pues, forma de evitar el relativismo.

${ }^{28}$ W. Pannenberg y otros, La revelación como historia, Sígueme, Salamanca, 1970, p. 117.

${ }^{29}$ Ibid. Véase también, del mismo Pannenberg, Wissenschaftstheorie und Theologie, Suhrkamp, Frankfurt, 1973, p. 304. p. 233.

${ }^{30}$ W. Dilthey, Gesammelte Schriften, Vandenhoeck\&Ruprecht, Göttingen, 1933, vol. VII,

${ }^{31}$ Ibid. Puede verse también M. Fraijó, «Religión y relativismo», En L. Arenas, J. Muñoz, A. J. Perona (eds.), El desafio del relativismo, Trotta, Madrid, 1997, p. 163. 
Consciente de esta dificultad, también Pannenberg revalorizó el final de la historia. Llegó incluso a escribir: «La revelación no tiene lugar al comienzo, sino al final de la historia revelante» ${ }^{32}$. Pero, con semejante desplazamiento hacia el final, el curriculum divino sufre mayor precariedad aún. En efecto: todo queda pendiente de un misterioso final con el que la filosofía, por ejemplo, no sabe muy bien qué hacer. Sin embargo, precisamente a la filosofía acudió Pannenberg para salir del atolladero. Conocedor de que tanto Dilthey como Heidegger habían revalorizado el concepto de anticipación, Pannenberg lo introdujo con inusitada fuerza en la teología posterior a la Segunda Guerra Mundial e intentó mostrar que el «final de la historia» no es una fecha que deba ser esperada pacientemente, sino un acontecimiento - la resurrección de los muertos - que ha quedado anticipado en la resurrección de Jesús de Nazaret. La resurrección de Jesús descifra y anticipa, pues, el final de la historia y mitiga la precariedad del curriculum divino. A través de ese acontecimiento, piensa Pannenberg, la revelación divina alcanza su máxima expresión. Solo falta un «pequeño detalle»: hay que probar la historicidad de la resurrección de Jesús. Pannenberg se empleó a fondo en ello, pero nosotros no le podemos acompañar esta tarde en su esfuerzo. Esfuerzo que la filosofía contempla con cierto pasmo, aunque la problemática no le debería ser ajena. Si se reemplaza el término «resurrección» por el de «inmortalidad del alma», la filosofía no tendrá más remedio que darse por aludida. Y no hay que olvidar que ambos términos apuntaron siempre en la mima dirección: el no acabamiento definitivo de los seres humanos tras su muerte, la huída de la nada. Pero, a pesar de tantos esfuerzos argumentativos, el curriculum de Dios continúa siendo muy precario. Y a un curriculum precario corresponde una recepción problemática.

\section{b) Una recepción problemática}

Fue M. Buber quien acuñó la expresión «eclipse de Dios»» ${ }^{33}$. Probablemente, Dios ha conocido muchos eclipses. En el siglo XIX, Nietzsche certificó su defunción. Anunció al mundo que, por fin, Dios, y la metafísica que implicaba, habían dejado de ser determinantes. Con gran solemnidad detalló las razones de su insignificancia. Sin embargo, el actual eclipse parece más decisivo que los anteriores, personalmente lo considero el más decisivo de todos los eclipses conocidos. Se prescinde de Dios distendidamente, sin los desgarros interiores de antaño, serenamente. Kolakowski encuentra preocupante que a la pregunta «¿qué hay de la cuestión de Dios?» se responda con

32 W. Pannenberg, op. cit., p. 123.

${ }_{33}$ M. Buber, Eclipse de Dios. Estudios sobre las relaciones entre religión y filosofía, Sígueme, Salamanca, 2003. 
naturalidad: «¿Pero es que existe realmente esa cuestión?» No existe, sostiene Kolakowski, para los creyentes «si los hay». Kolakowski piensa en creyentes «cuya fe heredada es firme e inconmovible». Para ellos no existe la «cuestión de Dios». Y tampoco existe, por supuesto, para los ateos convencidos —Kolakowski añade también aquí la apostilla «si los hay»— ya que «ellos saben sin ningún género de dudas que la ciencia ha expulsado a Dios definitivamente del mundo ${ }^{34}$.

Es indudable que existen creyentes de fe «firme e inconmovible», pero ellos no agotan el espectro. Se da también una recepción problemática de la fe en Dios. Hay creyentes que se debaten entre la fe y la increencia, entre el «sí y el no». Algunos se sienten tentados de repetir con Primo Levi, un superviviente de Auschwitz: «Existe Auschwitz, por lo tanto no puede haber Dios». Pero tal vez es más frecuente que se sientan envueltos en la dialéctica de E. Wiesel, otro superviviente del holocausto: «Auschwitz jamás se puede comprender con Dios; Auschwitz no se puede comprender sin Dios» ${ }^{35}$. Otros, no sé cuántos, es posible que den la razón a Wiesel cuando constata que, después de aquella crueldad, «hagamos lo que hagamos, estamos perdidos» ${ }^{36}$.

También es indudable, como sostiene Kolakowski, que «hay ateos convencidos». Pero tampoco ellos agotan la galería. Existe una recepción problemática de la convicción atea. De hecho, los ateos de ayer son, en parte, los agnósticos de hoy. Algo que probablemente no se debe sólo, como afirma F. Savater, a la falta de coraje para llamarse ateo en una sociedad dominada aún por la «turba levítica», sino a la posibilidad de que el agnóstico mantenga abierta alguna ventana a la creencia que el ateo habrá cerrado cuidadosamente. Y, como he sugerido más arriba, en diálogo con Muguerza, tal vez exista el increyente heterodoxo, o flexible, que no excluye por completo la solución escatológica cristiana.

\section{AUGE DE LAS RELIGIONES: EL ECLIPSE DE DIOS}

\section{Dios como problema}

Lo de Dios está conociendo, pues, una recepción problemática que justifica un discurso sobre «Dios como problema». Siempre me impresionó un fragmento de Protágoras: «Acerca de los dioses yo no puedo saber si existen o no, ni tampoco cuál sea su forma; porque hay muchos impedimentos para

${ }^{34}$ L. Kolakowski, «Die Sorge um Gott in einem scheinbar gottlosen Zeitalter», en H. Rössner (hrsg.), Der nahe und ferne Gott, Berlin, 1981, p. 9.

35 J. B. Metz, E. Wiesel, Esperar a pesar de todo, Trotta, Madrid, 1996, p. 99.

36 Ibid. 
saberlo con seguridad: lo oscuro del asunto y lo breve de la vida humana $\rangle^{37}$. Lo «oscuro del asunto» se corresponde con lo que he llamado «un curriculum divino precario». Lo «breve de la vida humana» tal vez juegue a favor de Dios, si es permitido hablar así. En efecto: unas búsquedas suceden a otras. Cuando, cansados de preguntar y buscar, nos acoge la muerte, van naciendo otros que inician su aventura religiosa con la misma ingenuidad e ímpetu que, un día lejano, fueron el sello de la nuestra. De esta forma, Dios nunca se queda sin interlocutores. Entre los que le buscaron a tiempo completo estará, sin duda, Pascal. Uno de sus Pensamientos también viene en ayuda de todo el que experimenta a Dios como problema, como asunto incierto: «Incomprensible que exista Dios e incomprensible que no exista» ${ }^{38}$. Y es que, si Dios no existe, quedan muchas cosas por explicar; pero, si existe, se amontonan igualmente los interrogantes.

Platón, ya en su ancianidad, dio un sabio consejo: «Hijo mío (...), el paso del tiempo te hará cambiar de opinión en muchos puntos y pensar al revés de como piensas ahora. Aguarda, pues, hasta entonces para zanjar cuestiones de tanta importancia. Y, aunque para ti no cuenta, la más importante es pensar correctamente (orthos) en el tema de los dioses» ${ }^{39}$. Entiendo que Platón invita a dejar abierto el tema. Algo tal vez no muy lejano de lo que vengo proponiendo en estas páginas. Hablar de Dios como problema es, en algún sentido, seguir «apegado» a él, no descartar por completo la sorpresa, la enorme sorpresa, de que exista. La teología alemana prefiere hablar de Dios como «pregunta» (Frage) en lugar de cómo «problema» (Problem). En general, las religiones se inclinan por el término «misterio» ${ }^{40}$.

En el tema de la recepción habría que distinguir dos ámbitos. Al primero se le suele llamar contexto de descubrimiento. Es el ámbito de la experiencia religiosa directa y originaria, previo a cualquier reflexión filosófica o teológica. Es el auténtico lenguaje primero del creyente. A esta experiencia, mezcla de fascinación y temor, de asombro y anhelo, no se le pueden fijar límites. Es el «reconocimiento extático del misterio» (M. Eliade), el abandono de todo lo penúltimo y provisional en favor de una realidad totalmente diferente que recibe muchos nombres. Es un ámbito en el que no se puede prescribir nada. No se puede, por ejemplo, obligar a nadie a que experimente a Dios como problema. Es el espacio en el que manda lo que nos «concierne incondicionalmente» (P. Tillich).

37 Véase F. Copleston, Historia de la filosofia I, Ariel, Barcelona, 1984, p. 103.

38 B. Pascal, Pensamientos, Colección Austral (ed. Brunschvicg), Madrid, 1967, fragmento 130 .

${ }^{39}$ Leyes X, 88 a b.

${ }^{40}$ He tratado esta problemática en mi libro, Dios, el mal y otros ensayos, Trotta, 2006, pp. 181-207. Véase, sobre todo, la obra de José Gómez Caffarena, El enigma y el misterio. Una filosofía de la religión, Trotta, 2007. Este libro contiene la sabiduría y madurez de toda una vida dedicada a la reflexión filosófica. Cf. también sus Diez lecciones sobre Kant, Trotta,Universidad Pontificia Comillas, 2010. 
Las cosas cambian cuando nos referimos al segundo ámbito, al del contexto de fundamentación. Es el encargado de articular conceptualmente la experiencia religiosa. Es el espacio del lenguaje segundo, la hora de la filosofía y de la teología. Aquí no manda la inmediatez perceptiva, sino un discurrir sosegado, riguroso y coherente. Es el ámbito del pensamiento, del concepto, de la argumentación, de la búsqueda razonada de la verdad. Es la esfera de los asertos, de las aseveraciones, de los pronunciamientos doctrinales, de las formulaciones. Es el turno del lenguaje, siempre relativo, inadecuado e históricamente condicionado. Un ámbito en el que, a mi entender, es posible hablar de Dios como problema. Para muchos será incluso obligado.

Finalmente: la recepción de un discurso problemático sobre Dios no será la misma en la teología y en la filosofía. El ritmo de aproximación al tema «Dios» es diferente. Es un terreno en el que la teología tiene obligaciones de mayor entidad. El ritmo filosófico de acceso a Dios — incluso el de la filosofía de la religión - será siempre laborioso, titubeante, interrogativo, problemático. El de la teología, en cambio, puede ser, aunque no necesariamente - piénsese en la teología fundamental — más directo, más asertórico y firme. La filosofía puede retrasar indefinidamente la aparición del tema «Dios» en el horizonte de sus preocupaciones. Puede ponerlo entre paréntesis sin mala conciencia, aunque históricamente apenas haya ocurrido en Occidente. W. Weischedel ha dedicado dos volúmenes a mostrar hasta qué punto la filosofía occidental se convirtió en una doctrina filosófica sobre el Dios cristiano. Su tesis es que, cuando esto ha dejado de ocurrir, la filosofía occidental ha entrado en crisis ${ }^{41}$. Lo que ya no sé es si la filosofía puede obviar por completo el tema «Dios». Imagino que una filosofía sectorial tal vez sí. En cambio, una filosofía — no sé si decir «metafísica»- que se interrogue por la realidad en su conjunto es posible que se vea obligada a echar un vistazo a lo de Dios.

La categoría principal del pensamiento filosófico es la razón. Es ella la que marca etapas y posibilidades de acceso a Dios. La teología, en cambio, concede mayor protagonismo a facultades menos severas: la imaginación, el sentimiento (Schleiermacher), los afectos. Aunque, para ser justos, hay que señalar que las tradiciones occidentales - tanto las filosóficas como las teológicas, tan difíciles de separar- han cultivado ambas vías. La vía, digamos, más cordial, tiene sus hitos principales en Platón, san Agustín, san Buenaventura, el maestro Eckhart, el Cusano, Pascal, Kierkegaard, Schleiermacher, Unamuno... Ha sido esta una vía de acceso a Dios generosa, amplia, y de grandes horizontes. Dio carta de ciudadanía a la experiencia, al sentimiento, a la mística, a los avatares de la vida.

${ }^{41}$ W. Weischedel, Der Gott der Philosophen, 2 vols., Deustscher Taschenbuch Verlag, Müchen, 1985. 
La otra vía, más austera y racional, puede remitirse a Aristóteles, san Anselmo, santo Tomás de Aquino, Descartes, Leibniz, Spinoza, Kant, Hegel, Heidegger... Ha cultivado una fidelidad casi heroica a la razón. Lo suyo ha sido la sobriedad racional. Descuidó, de esta forma, otros caminos a los que hoy somos más sensibles. El ideal sería, naturalmente, un cruce de tradiciones que Unamuno formuló así: «Piensa el sentimiento, siente el pensamiento». Se trata de una doble ciudadanía - Atenas y Jerusalén - difícil de obtener. Unamuno se pasó la vida solicitándola, pero nunca la consiguió. Se mantuvo en la «agonía», en la lucha, hasta su muerte, el 31 de diciembre de 1936. Unos años antes, en 1924, había escrito: «Agoniza el que vive luchando, luchando contra la vida misma. Y contra la muerte». Pero esta última batalla siempre se pierde.

\section{El giro antropológico}

Los cambios son siempre lentos y trabajosos. Sus protagonistas no son fáciles de identificar. En nuestro caso, la pérdida de la hegemonía divina no es, como hemos visto, atribuible a un solo factor ni a una sola persona. Pero lo cierto es que, lentamente, la subjetividad humana se fue convirtiendo en instancia suprema. Agotadas las posibilidades de lo divino, se impuso explorar lo humano. La filosofía de la religión se convirtió en una especie de antropología filosófica fundamental.

El giro antropológico estaba, pues, en marcha. Había sonado la hora de las religiones. Un giro del que ni siquiera la teología cristiana se vio libre. Schleiermacher, el padre de la teología protestante del siglo XIX, apenas encuentra sitio para Dios en sus ya citados Discursos. «El Kant de la teología protestante», como llamó D. F. Strauss a Schleiermacher, apenas habla - me refiero solo a los Discursos, no al resto de su obra - de Dios y la inmortalidad, admitidos por Kant como postulados. Con toda la claridad deseable escribe: «Ella - la religión- permaneció en pie para mí cuando Dios y la inmortalidad se esfumaron ante mis ojos vacilantes ${ }^{42}$. Schleiermacher informa de que hizo una breve visita a Kant y no le causó una impresión especial. Como el resto de los románticos, Schleiermacher parece contentarse con una escatología inmanente. No aspira a otra vida en un más allá garantizado por Dios, sino a la intensificación de ésta en el más acá. La inmortalidad consiste en fusionarse con el Infinito aquí y ahora. Se trata de «ser eterno en un instante», de compenetrarse con el Universo. Es llamativo: mientras Schleiermacher identifica la esencia de la religión con el gusto por el Universo, Santayana afirma: «El mayor logro de la religión

${ }^{42}$ F. Schleiermacher, Sobre la religión. Discursos a sus menospreciadores cultivados, pp. LI s. 
ha sido no permitir al hombre sentirse a gusto en el universo» ${ }^{43}$. Y es que, para Schleiermacher, Universo e Infinito son términos intercambiables; en cambio, para Santayana, el Infinito hacia el que tiende la religión está más allá del universo. De ahí que la meta de la religión consista en proyectar al hombre fuera del universo.

El «genio religioso de la filosofía trascendental alemana» —así llamó Dilthey a Schleiermacher en la genial biografía que le dedicó- buscó para la religión la misma autonomía que Kant había procurado a la moral. Le quiso adjudicar «una provincia propia en el ánimo», en el sentimiento. «Lo que yo siento es lo fundamental», concluyó D. F. Strauss al terminar de leer los Discursos. Se trata de un elogio de la subjetividad tan conciso como rotundo. No puede extrañar que Feuerbach tome a Schleiermacher, a quien considera el último teólogo del cristianismo, como decisivo aval de su intento de antropologización de la teología y de la religión en general. Y tampoco sorprenderá a los conocedores de Hegel la enorme reticencia con que éste contempló el subjetivismo religioso de los románticos en general y de Schleiermacher en particular. No comprendía Hegel que todo se reduzca a «tener religión»y se considere «indiferente si se sabe algo de Dios o no». De ahí sus sonados desencuentros con Schleiermacher.

Pero el Schleiermacher de los Discursos lo tiene claro: la religión es como un huerto que se cultiva por él mismo, sin pensar en posibles rendimientos. Es una «provincia propia» que no se confunde con la ética ni con la cultura. Su autonomía es tan nítida que no depende de sus dogmas ni de sus contenidos. Aunque éstos se difuminen, la religión permanece. Es más: frente al viejo aserto «ningún Dios, ninguna religión», Schleiermacher defiende la posibilidad de una religión sin Dios. Considera que puede ser incluso mejor, más desinteresada, que otra con Dios. Es la «piedad atea» de los románticos, la «mística de la trascendencia vacía» de Baudelaire, la «mística de la nada» de Mallarmé, o el «trascender sin Trascendencia» de Bloch.

Pero, ironías de la historia, a pesar de recibir tanto agasajo romántico, la religión llegó maltrecha y desprestigiada al siglo xx.

\section{El concepto de religión en apuros}

A pesar de la «santa revolución» de los románticos (Novalis, Hölderlin, los hermanos Schlegel) en favor de la religión, ésta sufrió un aparatoso derrumbe. Decir «religión» en la Alemania de comienzos del siglo xx era nombrar a un enfermo terminal. Los grandes filósofos del siglo anterior la habían p. 315 .

${ }^{43}$ Citado por W. Kaufmann, Crítica de la religión y la filosofía, México, FCE, 1983, 
tratado con una severidad quizás nunca antes alcanzada. Los nombres de Feuerbach, Marx, Nietzsche y Freud son paradigmáticos. Se atrevieron a quebrantar la moderación con la que la Ilustración alemana había agenciado los temas religiosos. Es sabido que, en contraste con el carácter iconoclasta de la Ilustración francesa, los ilustrados alemanes fueron constructivos y respetuosos con la andadura religiosa de Europa. En lugar de echar a pelear la razón y la fe, dedicaron sus mejores energías a intentar compaginarlas. Hegel había insistido en que pretendía suprimir «la grieta», «el muro divisorio», que se interponía entre la razón y la fe, entre la filosofía y la teología. Y, antes de Hegel, prestaron esos buenos servicios pensadores como Leibniz, Lessing, Herder y, por supuesto, Kant.

Ahora todo era distinto. El ataque más decisivo contra la religión vino precisamente de Feuerbach, inicialmente un entusiasta discípulo de Hegel. Le buscó a la religión un compañero sumamente incómodo: la asoció con el término alemán Bedürfnis (necesidad, indigencia, precariedad, desamparo). La religión, sentenció, es el pararrayos con el que los seres humanos intentan desviar males e infortunios. Es, como diría Marx, opio para el pueblo. Feuerbach la ve como un calmante de efecto pasajero que, además de no curar, aliena a los humanos. La religión encomienda al cielo, a Dios, lo que solo la tierra, los hombres, pueden remediar. Feuerbach lo tiene claro: de los que miran hacia arriba, hacia el cielo, de los orantes, hay que hacer trabajadores.

$Y$ ya se sabe: el primer premio en asuntos de desgracia y radical desamparo se lo lleva siempre la muerte. «Si el hombre no tuviera que morir, repetía Feuerbach, no habría religión». Cabría tal vez objetar que también para vivir se requiere religión. No solo la muerte requiere apoyo y consuelo, sino también la vida. El coraje de existir se titula un exitoso libro de P. Tillich. La religión debe su permanencia en el tiempo no solo a que tenemos que morir, sino a que tenemos que vivir y queremos hacerlo con sentido. Ambos trances, tanto el vivir como el morir, requieren ayuda. Ayuda que, mediante sus símbolos y promesas, ofrecen generosamente las religiones. En realidad, las religiones son instancias de acompañamiento, ofertas de sentido, promesas de días futuros más benévolos y luminosos que los presentes. El cristianismo, por ejemplo, acompaña a sus fieles, a través de los sacramentos, desde la cuna hasta la tumba. Ninguna fecha de dolor queda sin alivio. Tal vez por eso decía K. Rahner que no había encontrado nada mejor que el cristianismo. Morimos en una radical soledad que quizás solo las religiones quebrantan con anuncios de "otra vida». Puede que sean ellas la última compañía, nuestro último interlocutor, el postrer consuelo de muchos seres humanos. Ortega y Gasset se quejaba de que ninguna cultura ha enseñado al hombre a ser «lo que constitutivamente es: mortal». Y H. Jonas escribe: «Desde tiempos inmemoriales los mortales han lamentado su mortalidad, han intentado escapar a ella y se han aferrado a la esperanza en una vida eterna. Cuando digo los "mortales" me refiero evidentemente a los seres humanos. 
Entre todas las creaturas solo el ser humano sabe que tiene que morir, solo él llora a sus muertos, los entierra y los recuerda. La mortalidad se ha considerado hasta tal punto como característica de la condición humana, que el atributo "mortal" casi se ha monopolizado para el ser humano»" ${ }^{44}$. Animal guardamuertos» llamó Unamuno al ser humano. Y nunca se aprende a morir, tal vez ni siquiera a «creer en la propia muerte» (Freud). Sin embargo, la muerte es nuestra gran certeza. Heidegger dejó dicho que la muerte no es únicamente el «final» de la vida, sino su permanente «amenaza». Con razón escribía P. Laín: «Lo cierto es siempre lo penúltimo, y lo último es siempre incierto». Y, desde luego, la muerte no suele ser bienvenida. Es conocido el rechazo frontal que recibió de Unamuno: «No quiero morirme, no, no quiero ni quiero quererlo». La mayoría de las religiones, entre ellas el cristianismo, han dado su palabra de honor de que existe «otra vida». De ahí que Nietzsche atribuyese la victoria del cristianismo a «esa deplorable adulación de la vanidad personal» lograda a golpe de promesas de inmortalidad.

Marx consideró que Feuerbach, remitiendo el origen y el perdurar de la religión a los afanes de supervivencia más allá de la muerte, había hecho un buen trabajo. De ahí que escribiera: «Para Alemania, la crítica de la religión está en lo esencial concluida». La religión había sucumbido ante el «baño de fuego» que significa etimológicamente Feuer-bach. En algún sentido, Marx tenía razón. Después de los grandes críticos del siglo XIX, nada ha vuelto a ser igual. Ni Dios ni la religión se han recuperado por completo. En el interior de la creencia religiosa y de sus contenidos se ha instalado la pertinaz sospecha de la «mera proyección». Según ella, los diferentes entramados religiosos solo son atrevimientos de la fantasía humana, ficciones de sentido, paraísos imaginarios, finales felices para una realidad cruel; en definitiva, fruto de la rebeldía ante la muerte.

La peor parte, como hemos visto, se la ha llevado «Dios». La religión, como veremos a continuación, está conociendo nuevos retornos. Pero la Divinidad, constata K. Jaspers, «permanece oculta». Sin ella, el único «apoyo sólido» que nos queda es el de «tendernos la mano» unos a otros. No puede extrañar, pues, que, desde los días de la Ilustración, la ética venga ocupando el lugar que antaño nadie disputaba a la religión. «Solo la ética - escribió Feuerbach - es la verdadera religión». Es ilustrativa la «confesión» de B. Russell: he visitado, informa, muchos países y en ninguno de ellos me preguntaron por mi religión; pero en ninguno de ellos me permitieron matar, robar, mentir o cometer abusos sexuales. Su conclusión, una conclusión que en el mundo occidental es ya casi un bien común, es que sin religión se puede vivir, pero sin ética no. Entre paréntesis: las prohibiciones sufridas por B. Russell en sus viajes coinciden con el antiquísimo catálogo

${ }^{44}$ H. Jonas, Pensar sobre Dios y otros ensayos, Herder, 1998, p. 89. 
de preceptos morales esbozado por los fundadores de las grandes religiones y por las más antiguas filosofías.

\section{El retorno de la religión}

Feuerbach sembró una honda inquietud en los estudiosos del hecho religioso. Muchos, sobre todo los fenomenólogos, se aprestaron a buscarle a la religión un compañero más fiable que el que le había asignado Feuerbach. El grito de guerra fue: la religión no brota solo de la Bedürfnis (necesidad, precariedad), sino de la Erlebnis (experiencia, vivencia). Se quería poner de manifiesto que la religión no era, como sostenía Feuerbach, una proyección humana carente de contenido, sino un hecho objetivo en el que alguien se encuentra con Alguien o, al menos, con Algo. El esfuerzo se orientó a mostrar que la experiencia religiosa es algo más que un sofisticado proceso de autoescucha. No todo se reduce a percibir el eco de la propia voz, de los propios deseos de perdurar más allá de la muerte, en un vacío insondable. Se quería encontrar a la religión un firme anclaje en la realidad, una cita con la objetividad más allá de sentimientos y anhelos subjetivos. Se trata de una reacción comprensible, teniendo en cuenta que los hombres que intentaron revalorizar el concepto de religión en la Alemania de comienzos del siglo XX eran creyentes cristianos. Algunos, como R. Otto, el conocido autor de Lo Santo $^{45}$, eran teólogos.

Pero, paradójicamente, de la teología vino esta vez el peligro. La teología protestante se debatía entre dos tiempos sin tiempo propio. Por aquellos días declinaba la teología liberal. Su máximo representante, Adolf von Harnack, había pronunciado, al asumir el rectorado de la universidad de Berlín, un solemne discurso (en 1901), en el que rechazaba radicalmente la posibilidad de que la teología se abriese al estudio académico de las religiones no cristianas. La investigación de la historia de las religiones no debía formar parte del curriculum del estudiante de teología. Desgraciadamente, la voz de Harnack, tan poderosa por aquellos días, fue escuchada. Alemania tardó mucho en abrirse al estudio científico de las religiones no cristianas. La convicción generalizada de que el cristianismo era la única religión verdadera convertía en superfluo dicho estudio. ¿Para qué estudiar religiones que no son verdaderas si se tiene la suerte de formar parte de la única verdadera?

Y tampoco la teología dialéctica, que tomó el relevo de la teología liberal, mostró mayor sensibilidad en ese campo. Su principal representante, $\mathrm{K}$. Barth, compartía, al menos en su primera época, el rechazo de la teología liberal hacia las religiones no cristianas. Es más: Barth aceptó el veredicto de Feuerbach sobre la religión como proyección. Eso sí, dicho veredicto no

${ }^{45}$ R. Otto, Lo santo, Círculo de Lectores, Madrid, 2000. Estudio introductorio de M. Fraijó. 
afectaba al cristianismo que, según Barth, no es religión, sino fe. Por religión entiende Barth el esfuerzo humano para acceder a Dios. Un esfuerzo que el cristianismo nos ahorra, ya que en él es Dios quien toma la iniciativa y se nos hace cercano. El cristiano solo tiene que saber que Dios ha hablado. Dominus dixit, predicaba Barth.

La palabra del Dios cristiano es, según Barth, la Krisis de todas las religiones, es decir, el juicio negativo sobre ellas. Las religiones solo son intentos de autojustificación humana. No vale, pues, la pena estudiarlas. Solo un loco (Narr), afirma el padre de la teología dialéctica, puede esperar que el estudio de las religiones no cristianas contribuya a una mejor comprensión de la fe cristiana. Para hacer justicia a Barth, hay que reconocer que en su ancianidad concedía que, junto a «la única luz», había «otras luces» menores.

La crítica de la teología liberal y de la teología dialéctica supuso un auténtico mazazo para el concepto de religión y para sus estudiosos, sobre todo para los fenomenólogos. También la religión, heredera de la antigua fe en Dios, pasó a conocer días de incierto futuro. El auge de la religión no fue lineal. También las religiones conocieron días malos y altibajos notables. Pareció que nos quedábamos sin lo uno y sin lo otro, es decir: sin Dios y sin la religión.

El ambiente de las universidades alemanas se tiñó de teología dialéctica. En Marburgo, ciudad en la que enseñaba R. Otto, sus alumnos, en número insignificante, se veían ampliamente superados por el griterío del resto de los estudiantes, que hacían gala de un barthianismo, por lo demás generosamente simplificado. Un barthianismo al que unían su entusiasmo por la teología de Bultmann y por el existencialismo heideggeriano imperante.

Se trataba de los mismos estudiantes que ridiculizaban el pensamiento de Otto y hacían chistes sobre la colección de objetos religiosos que éste había reunido. Eran los objetos que Otto había ido coleccionando en los numerosos viajes que, para conocer religiones no cristianas, realizó. Fue el primer teólogo europeo viajero. Dotado de gran sensibilidad, el autor de Lo santo no pudo soportar tanta burla y, en 1929, cuando solo contaba sesenta años, pidió y obtuvo la jubilación. Una decisión en la que también influyó su delicado estado de salud.

Pero el buen trabajo de los fenomenólogos estaba hecho. Pasó la hora de la teología liberal y también de la teología dialéctica. En cambio, las ciencias de la religión (fenomenología, psicología, sociología, historia, filosofía) gozan hoy de envidiable salud. Y las religiones no cristianas, cuya defunción fue repetidamente anunciada por las citadas teologías, vienen hoy a misionar a Europa. Un teólogo tan perspicaz como W. Pannenberg avisaba, cuando todavía se consideraba al marxismo como el gran contrincante del cristianismo, de que el auténtico adversario de éste serían las restantes religiones. Hay que reconocer que no se equivocó. 
Los estudiosos de las religiones contribuyeron, pues, a poner fin al descrédito sufrido por el concepto de religión durante el siglo XIX. Feuerbach sigue sin ser refutado, pero se puso de manifiesto que todo era mucho más complejo de lo que él había imaginado. Es cierto que Dios no existe por el mero hecho de que el hombre lo desee; pero tampoco sería correcto afirmar: lo deseamos, luego no existe. Intervienen factores plurales que no es éste el momento de mencionar.

La revalorización del concepto de religión fue más fácil en los países sin tradición teológica. Las facultades de teología se resistían a que el estudio de la religión escapara a su jurisdicción. En los Estados Unidos de América, que carecían de dichas facultades, florecieron los Departments of religion como en ningún otro lugar. Las facultades de teología, en cambio, se lo jugaban todo a una única carta: el carácter absoluto del cristianismo. Y, si el cristianismo posee carácter absoluto, las restantes religiones se quedan sin espacio. Es la lucha entre el elefante y el ratón.

Se observará que el protagonista de los avatares que vengo narrando fue el protestantismo. El catolicismo estuvo bastante al margen de estos aconteceres. Por estas fechas dedicaba sus energías a luchar contra el modernismo. La rigidez de su esquema dogmático y el férreo control de su autoridad magisterial impidieron que en su interior surgieran figuras como Kant o Hegel, grandes maestros en el pensar la religión. Pero, en realidad, sin Kant ni Hegel, tampoco hay espacio para Schleiermacher, maestro en el sentir la religión. Y una religión ni pensada ni sentida puede dar lugar a una religión impuesta, o a ninguna religión. Desde luego no propicia una religión como «interioridad apasionada», la deseada por Kierkegaard y tantos otros.

Finalmente: ¿A qué clase de religión da lugar el eclipse de Dios? ¿Se puede prescindir, y con qué consecuencias, de la tradición teísta en las áreas geográficas en las que las religiones monoteístas han tenido un fuerte arraigo? Ofrezcamos un breve apunte.

\section{5. ¿Religión sin Dios?}

En una religión sin Dios nos encontraríamos, tal vez, ante lo que el fenomenólogo de la religión, G. van der Leeuw ha llamado religión «de la huida». Huida, por supuesto, de Dios y apelación a uno mismo. Estaríamos ante un concepto «débil» de religión en el que se entiende por ésta todo proceso de autoescucha, todo método de relajación para vencer el estrés, toda especie de cura humanística en la que se reponen fuerzas. La función de tal concepto de religión podría ser asumida por la música, por la poesía, o por cualquier otro mensajero de la belleza y la armonía. En definitiva estaríamos ante un conjunto de estaciones hacia uno mismo, hacia la propia paz y serenidad interior, hacia la propia autorrealización. 
Otra forma de entender un concepto de religión que huye de Dios sería la reflejada en la tercera cosmovisión metafísica de Dilthey, que él califica de «idealismo objetivo». Es la religión tal como la vivieron y sintieron Goethe, Hegel, G. Bruno, Spinoza, y algunos pensadores de la India y China. Es decir: la religión comprendida como una actitud contemplativa, expectante, estética y artística ante la vida. El individuo queda envuelto en una especie de simpatía universal. Un monismo reconfortante, consolador, lo invade todo. Se experimenta la riqueza y el valor de la vida. La persona se siente unida a todos los miembros y elementos de la creación. La solución de todos los problemas se vislumbra en una especie de armonía universal. La palabra mágica, como en Schleiermacher, es «sentimiento». El idealista objetivo es, sobre todo, un esteta. No se siente «creyente», pero sí «religioso». Una religiosidad difusa, casi invisible, generosa, profunda, tolerante, sin dogmas vinculantes. Una religiosidad que queda perfectamente reflejada en las palabras de Goethe: si buscas el Infinito, corre tras lo finito en todas direcciones. Me pregunto si no será ésta la única religiosidad que admiten muchos de nuestros contemporáneos. ¿No estamos viviendo de nuevo la estetización de la religión que aparece en los Discursos de Schleiermacher?

Cabe preguntar cómo queda la verdad de la religión cuando - siempre en países de tradición monoteísta - se la separa de la fe en Dios y se la convierte en alivio de melancolías e instancia estética. Debemos tener en cuenta que pensar la religión es, ante todo, pensar su verdad. Y no meramente su verdad funcional, es decir, la función - positiva o negativa- que cumple en la vida de sus adeptos. W. Cantwell Smith, misionero canadiense y gran estudioso de las religiones, insiste en el criterio del autorreconocimiento: los asertos sobre la religión solo son válidos si son reconocidos por los seguidores de tal religión. Me pregunto si el criterio del autorreconocimiento, en el que también insiste E. Trías ${ }^{46}$ y cuya crucial importancia admito, es suficiente. ¿No sería pertinente, siguiendo la estela de bastantes estudiosos del tema, acudir a un doble criterio de verdad: el interno (fidelidad al fundador y a los documentos fundacionales, interpretados críticamente), y el externo (cita ineludible con las exigencias éticas)? Reconozco que la terminología «interno-externo» no es precisamente un prodigio de originalidad, pero la sustancia de lo expresado me parece defendible. Tal vez no sería «igualmente verdadera» una religión que favoreciera y defendiera los derechos humanos, que otra que no lo hiciera. Ni gozaría de igual grado de verdad una religión que somete su legado originario a los rigores del análisis histórico-crítico, que otra que practique la estrategia de la inmunización apelando a una autoridad divina directa, inaccesible a la pregunta y a la

${ }^{46}$ E. Trías, Por qué necesitamos la religión, Plaza \& Janés, Barcelona, 2000. Véase también el ya citado Pensar la religión, Destino, Barcelona, 1997. 
crítica $^{47}$. Sin olvidar, naturalmente, el carácter escurridizo de la verdad, especialmente de la verdad de las religiones. Las religiones no trabajan la evidencia, sino la adhesión. Son comunidades narrativas, pendientes de una verificación escatológica que solo impropiamente puede ser calificada de «verificación». La única verificación de la verdad para los humanos es la que anunció nuestro poeta José Ángel Valente: «Murió, es decir, supo la verdad». Solo la muerte revelará la verdad última de las cosas y de las religiones, aunque acabo de acordarme de su implacable aserto en una película de Bergman: «yo no revelo nada».

Y algo de crucial importancia: si se silencia a Dios, si se consuma la separación entre religión y Dios ¿qué instancia podría colmar el «deseo radical» de «salvación», tan presente en la historia de las religiones? ¿Encomendaremos a nuestros difuntos a la estética? ¿Los encomendaremos a la religión sin Dios? La apuesta por la no frustración definitiva de ese deseo radical, por un sentido final de la existencia, constituye también el nervio de muchas filosofías. Son muchas, y muy nobles, las páginas que la filosofía ha consagrado a postular un buen final para la vida de los seres humanos.

Pero, sin Dios, el único final posible son las «paletadas de tierra» que alguien arrojará sobre nuestros despojos y que ensombrecían y enlutaban la esperanza de Bloch. Se nos despedirá con música, pero la música no nos salvará. Dicho de otra forma: la salvación que ella ofrece no es la «salvación radical» invocada por los seres humanos y anunciada por sus religiones. El «trascender sin Trascendencia», de Bloch, tiene fecha de caducidad: la muerte. Los cadáveres no trascienden nada. En su acepción fuerte, en su radicalidad última, la salvación tiene que ver con el destino final del ser humano $\mathrm{y}$, por tanto, con la posibilidad de que su muerte no lo reduzca a la nada. Hablar de salvación es inscribir a la muerte en un marco de dramaticidad no absoluta. Tarea imposible, creo, si no se apela a la Trascendencia con mayúscula, es decir, a Dios. Unamuno narra su encuentro con un campesino que, con algo de sorna, le asegura que un Dios que no resucite a los muertos no sirve para nada.

La salvación es, pues, una promesa de futuro, de índole escatológica, que no resiste comprobación histórica alguna. No es datable ni verificable. Se comprende la incomodidad de la filosofía ante ella. La gran mayoría de sus diccionarios no incluyen el término. Es más: en los años setenta, dominados por la fiebre de la secularización, hubo teólogos que reemplazaron «la salvación del hombre» por «el bien del hombre». Consideraban el concepto de salvación lastrado por un tufillo excesivamente sacral. Hoy nos quedan lejos semejantes escrúpulos, y semejante ignorancia. La fenomenología de la reli-

47 Véase H. Küng, Proyecto de una ética mundial, Trotta 1990. Cf. además, El cristianismo. Esencia e historia, Trotta, 1997. Véase también Karl-Josef-Kuschel, Discordia en la casa de Abrahán, Evd.Estella, 1996. 
gión avala inequívocamente la centralidad del término «salvación» en la historia de las religiones.

Pero, de nuevo: ¿a quién encomendar, o de quién esperar dicha salvación, si se da por muerto a Dios y se acepta su eclipse total? Kant, movido según Adorno «por el ansia de salvar», se atrevió, como hemos visto, a postular la inmortalidad y, como su condición de posibilidad, la existencia de Dios. Vale la pena ofrecer una cita de Adorno: «Si la razón kantiana se siente impulsada a esperar contra la razón es porque no hay mejora en este mundo que alcance a hacer justicia a los muertos, porque ninguna mejora afectaría a la injusticia de la muerte» ${ }^{48}$. El secreto de la filosofía kantiana, concluye Adorno, «es la imposibilidad de pensar la desesperación» ${ }^{49}$. Desesperación que saldría completamente victoriosa si, más allá de la muerte, no existe instancia alguna capaz de «recomponer lo despedazado» (W. Benjamin), de ofrecer «salvación radical».

Tiene razón F. Savater cuando, desde su ateísmo, al analizar el libro de G. Vattimo, Creer que se cree, echa de menos en él los temas fuertes del cristianismo, como la resurrección de los muertos. Sostiene que «puestos a creer... es eso y no otra cosa más débil lo que merece la pena de creerse ${ }^{50}$. Desde tiempo inmemorial, muchos seres humanos, nunca sabremos cuántos, parecen haber confiado en que sus deseos más constitutivos y esenciales conozcan mejor destino que su extinción forzosa en la nada. No era solo Unamuno quien se resistía a que la vida se agote en «una fatídica procesión de fantasmas, que van de la nada a la nada... ${ }^{51}$.

Hay, sin embargo, otras melodías, otras voces que no conviene silenciar. A. Flew, el ateo recién "convertido» al teísmo después de más de cincuenta años de estricto ateísmo, escribe: «No me veo "sobreviviendo" a la muerte». Su conversión le ha conducido a aceptar la existencia de Dios, pero no a creer en la «existencia de una vida de ultratumba». Con toda la claridad deseable escribe: «Quede constancia, pues, de que deseo silenciar todos esos rumores que me presentan haciendo apuestas pascalianas ${ }^{52}{ }^{52}$ Y ¿cómo olvidar la contundente confesión de Rilke: «Cada cosa en su momento. Justo en su momento y nada más. Y nosotros también en nuestro momento. Y nunca más?» ${ }^{53}$.

El mismo Aranguren, cristiano heterodoxo, creía que las religiones no deberían apostarlo todo a la carta de la resurrección. En este aspecto se reconocía poco unamuniano, no le importaba la perduración de su «yo» tanto

48 Th. W. Adorno, Dialéctica negativa, Taurus, Madrid, 1989, p. 384.

${ }^{49}$ Ibid., p. 385.

${ }^{50}$ F. Savater, El País (Babelia), 27 de julio de 1996, p. 11.

${ }_{51} \mathrm{M}$ de Unamuno, Del sentimiento trágico de la vida, Espasa-Calpe, Madrid, 1967, p. 39.

${ }_{52}$ A. Flew, Dios existe, Trotta, 2012, p. 36. p. 821.

53 Tomo la cita de D. S. Toolan, Reencarnación y gnosis moderna, Concilium 249, 1993 , 
como a Unamuno. Dejaba, como sabemos, la posibilidad de la resurrección en puntos suspensivos...Se trata de una opción altamente respetable y muy acorde con la naturaleza misteriosa, al borde de lo desorbitado, del anuncio cristiano.

Sin embargo, más allá de los siempre respetables anhelos personales, tropezamos con la memoria de las víctimas de la barbarie humana. Si postulamos la resurrección, lo hacemos sobre todo en su honor. A nosotros, nacidos en países y días de bienestar material, puede que nos haya bastado con esta vida; pero las víctimas, las de Auschwitz y las de tantos otros holocaustos, carecieron de todo. Alguien decidió que eran material eliminable, pura mercancía. F. Savater suele decir que lo importante no es que haya vida después de la muerte, sino que la haya antes. De acuerdo. Pero, cuando esto no ocurre, es legítimo aferrarse al «después», aunque solo sea como gesticulación impotente, como protesta testimonial. Hegel escribió que, cuando se insiste mucho en el lado oscuro de la vida es porque se desea aparentar que se es «buena persona», que se tienen «buenos sentimientos». Es posible, aunque no siempre tenga que ser así. La insistencia en la negatividad también puede tener su origen en el firme convencimiento de que los expedientes de las víctimas de la injusticia no deberían ser archivados sin reparación. Los orígenes judeocristianos de la fe en la resurrección parecen poner de manifiesto que ésta solo estaba destinada a los mártires. Era su martirio el que no podía quedar injustamente olvidado. Se estaba en deuda con ellos, se les debía otra oportunidad, oportunidad que ofrecía la resurrección. La creencia en la resurrección es, pues, un canto a una justicia final que impida olvidos definitivos. Es el rechazo de la nada como estación final.

¿Cómo no recordar en este contexto los versos de H. Heine?

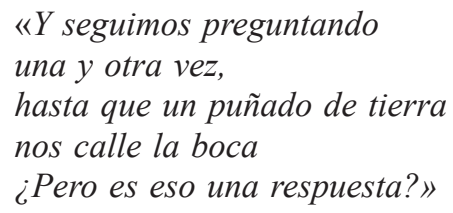

Precisamente porque eso no es una respuesta surgió la creencia en Dios $\mathrm{y}$ en los dioses, surgieron las religiones con sus libros sagrados, sus «hombres decisivos» (K. Jaspers), sus templos, su culto a los muertos, sus cuidados cementerios, sus filosofías y teologías. Todo en ellas apunta hacia nuevos amaneceres, hacia vidas nuevas y sanadas, hacia futuros luminosos, hacia una generosa recomposición de lo que fue y dejó de ser, hacia inicios nuevos de vidas truncadas. La historia de la humanidad muestra que no hemos sido proclives a la resignación.

Mircea Eliade se ha fijado en las tradiciones de una tribu arunta, los achilpa. Su dios, Numbakula, convirtió el tronco de un árbol gomífero en un poste sagrado. Lo untó con sangre, trepó por él y ascendió a los cielos. Dicho 
poste es, para los achilpa, una especie de eje cósmico. Toda la vida gira en torno a él. Lo llevan con ellos durante sus desplazamientos. Es él quien les permite estar en comunicación con el cielo en el que desapareció Numbakula. El problema surge si se rompe el poste; sobreviene entonces la catástrofe. Según M. Eliade, «se asiste en cierto modo al "fin del mundo", a la regresión, al caos». El mito cuenta que, «habiéndose roto una vez el poste sagrado, la tribu entera quedó presa de la angustia; sus miembros anduvieron errantes por algún tiempo y finalmente se sentaron en el suelo y se dejaron morir» ${ }^{54}$.

Esta historia puede ser un alegato a favor de puntos fijos, de fidelidades, de tradiciones, de valores, de pilares sólidos, de postes orientadores. Durante siglos, esa función corrió a cargo de las religiones. De forma atemática y no consciente es posible que, en parte, siga siendo así. Tal vez una especie de «religión invisible» continúe moviendo secretamente, más de lo que pensamos, los hilos de las conductas. Pero, si no fuese así, habría que buscar nuevas fuentes de energía espiritual. Sin postes sagrados, sin grandes principios, sin símbolos privilegiados, sin signos portadores de orientaciones vinculantes, no es posible la vida sobre la tierra. Desde siempre se asignó a la religión la función de señalar límites, de poner coto a la ilimitada capacidad humana de transgredir. Hay temor a una transgresión extendida, egoísta, desconocedora del límite. De nuevo: si la religión careciera ya de autoridad para cumplir esa función reguladora, habría que orientar la búsqueda hacia otros manantiales.

Pero estas «Conferencias Aranguren» solo pretendían romper una lanza a favor de un concepto fuerte de religión, que no huya de la incomodidad filosófica que supone afrontar el problema de Dios y preguntarse por el destino final de los seres humanos tras su muerte. Occidente está acostumbrado a la desmesura de tales preguntas. Las religiones que le tocaron en suerte, las monoteístas, son un permanente ir y venir de Dios al hombre. De ahí que sea legítimo e incluso obligatorio preguntar, como hemos hecho, a qué clase de religión daría lugar la asunción de la muerte de Dios y la extinción de las grandes preguntas relacionadas con él. Estaríamos, como hemos puesto de relieve, ante una religión de la huída, más ocupada en engalanar la inmanencia que en preguntar por la Trascendencia. En definitiva, una religión del cuidado de sí mismo, estetizante y bien avenida con casi todo.

En 1931, a su vuelta de una prolongada estancia en los Estados Unidos, D. Bonhoeffer, que solo contaba entonces 25 años, confesó a un amigo que deseaba visitar la India «por si de allí viene la gran solución». Consideraba que en Europa se había dado ya «la gran muerte del cristianismo» (das grosse Sterben des Christentums) $)^{55}$.

${ }_{54}$ M. Eliade, Lo sagrado y lo profano, Labor, 1983, p. 35.

${ }_{55}$ Véase H. Zahrnt, Gott kann nicht sterben, Deustscher Bücherbund, Stuttgart, 1970, p. 113. 
No parece probable que Europa pueda convertirse, desde el punto de vista religioso, en una especie de sucursal oriental. Pesa mucho la propia historia monoteísta. Ni de la India, ni de ningún otro lugar, puede venir «la gran solución». En primer lugar, porque la gran solución no existe. De la India, y de otras latitudes, vendrán, han venido ya, impulsos, complementariedad, corrección de unilateralidades. En segundo lugar, porque en Europa la solución tendrá que ser europea. Y, por tanto, al menos culturalmente monoteísta y prevalentemente cristiana.

Algo con lo que parece estar de acuerdo J. Habermas: «El cristianismo representa para la autocomprensión normativa de la modernidad no solo una forma precursora o un catalizador. El universalismo igualitario, de donde proceden las ideas de libertad y convivencia solidaria, así como las de forma de vida autónoma y emancipación moral de la conciencia individual, derechos humanos y democracia, es directamente una herencia de la ética judía de la justicia y de la ética cristiana del amor. Inalterada en su sustancia, esta herencia ha sido asimilada una y otra vez de manera crítica e interpretada de nuevo. Cualquier otra cosa sería palabrería posmoderna ${ }^{56}$. Y, al recibir el Premio de la Paz, otorgado por la Asociación de Libreros y Editores de Alemania en 2001, en el silencio sobrecogedor de la iglesia de san Pablo, afirmó que «la esperanza perdida de la resurrección se siente a menudo como un gran vacío». Y evocó el intercambio epistolar entre Benjamin y Horkheimer sobre el futuro de las víctimas de la barbarie. Ambos estuvieron de acuerdo en no desechar de antemano la solución teológica, en dejar abierta una puerta por la que pudiese entrar una solución final escatológica, distinta de la de Hitler.

Es, pues, mucho lo que Europa ha heredado del judaísmo y del cristianismo. Pero las herencias nunca obligan a ser aceptadas en su integridad. Habermas renuncia a la herencia escatológica, aquélla a la que más atención ha querido prestar mi exposición. Sin ella, creo, el cristianismo sufre una mutilación esencial. Un cristianismo que no sea escatología, dejó dicho K. Barth, dejaría de ser cristianismo.

Comencé estas Conferencias evocando la figura de Aranguren y así las quiero terminar. Hacia el final de su artículo sobre la muerte de su maestro y amigo, Eugenio D’Ors, Aranguren escribió: «El espíritu no muere, el diálogo prosigue, la palabra no puede extinguirse».

En ello estamos. Continuamos a vueltas con el diálogo, con la palabra, con el espíritu, con la religión, con Dios. Aranguren reposa en el cementerio de Ávila, la ciudad que él evocó como «lejana, entre pétrea y mística», la ciudad en la que nació y a la que quiso «ser llevado a reposar». Pero su herencia, su huella permanece. Dieciséis años después de su muerte, su me-

56 J. Habermas, Israel o Atenas, Trotta, 2001, p. 185. Cf. También, del mismo Habermas, Entre naturalismo y religión, Paidós, 2006. 
moria, su recuerdo cariñoso ha sido lo suficientemente fuerte para reunirnos estas dos tardes en la Residencia de Estudiantes.

\section{BIBLIOGRAFÍA}

Adorno, Th. W.: Dialéctica negativa, Taurus, Madrid, 1989.

Armstrong, K.: En defensa de Dios. El sentido de la religión, Paidós, 2009.

Buber, M.: Eclipse de Dios. Estudios sobre las relaciones entre religión y filosofía, Sígueme, Salamanca, 2003.

Camps, V.: La imaginación ética, Ariel, Barcelona, 1991.

Camps, V. y Valcárcel A.: Hablemos de Dios, Taurus, 2007.

Cioran, E. M.: Del inconveniente de haber nacido, Taurus, Madrid, 1982.

Collins, J.: The Emergence of Philosophy of Religion, New Haven-London, 1967.

Conill, J.: El crepúsculo de la metafísica, Anthropos, 1998.

Cortina, A.: Ética de la razón cordial, Nobel, Oviedo, 2007.

Dawkins, R.: El espejismo de Dios, Espasa, 2007.

Dilthey, Gesammelte Schriften, Vandenhoeck \& Ruprecht, Göttingen, 1933, vol. VII.

Duch, L.: Un extraño en nuestra casa, Herder, 2007.

Eliade, M.: Lo sagrado y lo profano, Labor, 1983.

Estrada, J. A.: La imposible teodicea. La crisis de la fe en Dios, Trotta, 1997.

Feiereis, K.: Die Umprägung der natürlichen Theologie in Religionsphilosophie, Leipzig, 1965.

Fierro, A.: Sobre la religión, Taurus, 1979.

Fierro, A.: Historias de Dios, Laia, Barcelona, 1981.

Fierro, A.: Después de Cristo, Trotta, 2012.

Flew, A.: Dios existe, Trotta, 2012.

Flores D'Arcais, P., Onfray M. y Vattimo G. (eds.): Ateos o creyentes, Paidós, Barcelona, 2009.

Fraijó, M.: A vueltas con la religión, Evd, Estella, 2012.

Fraijó, M.: Dios, el mal y otros ensayos, Trotta, 2006.

Fraijó, M.: El cristianismo. Una aproximación, Trotta, 2000.

Fraijó, M.: Filosofía de la religión. Estudios y textos, Trotta, 1994.

García Santesmases, A. (ed.): La izquierda, el poder y otros ensayos. José Luis l. Aranguren, Trotta, 2005.

Gauchet, M.: Lo religioso después de la religión, Anthropos, Madrid, 2007.

Gómez Caffarena, J.: El enigma y el misterio. Una filosofía de la religión, Trotta, 2007.

Gómez Caffarena, J.: Diez lecciones sobre Kant, Trotta, 2010.

Gómez, C., Muguerza, J. (eds.): La aventura de la moralidad, Alianza, Madrid, 2007.

Gómez, C. (ed.): José Luis Aranguren. Filosofía y vida intelectual. Textos fundamentales, Trotta-UNED, Madrid, 2010.

González de Cardedal, O.: Ética y religión, ed. Cristiandad, 1977.

González de Cardedal, O.: Dios, Sígueme, 2004.

Habermas, J.: Israel o Atenas, Trotta, 2001.

Habermas, J.: Entre naturalismo y religión, Paidós, 2006. 
Heidegger, M.: «Zeit und Sein», en Zur Sache des Denkens, Max Niemeyer, Tübingen, 1969.

Herrando, C: José Luis L. Aranguren, Fundación E. Mounier, 2006.

James, J.: Las variedades de la experiencia religiosa, Península, Barcelona, 1999.

Jonas, H.: Pensar sobre Dios y otros ensayos, Herder, Barcelona, 1998.

Jonas, H.: Memorias, Losada, Madrid, 2005.

Kant, I.: La religión dentro de los límites de la mera razón, Alianza, 1986.

Kant, I.: ¿Qué es la Ilustración?, (Edición de Roberto R. Aramayo), Alianza, 2004.

Kaufmann, W.: Crítica de la religión y la filosofía, México FCE, 1983.

Kolakowski, L.: Si Dios no existe..., Tecnos, Madrid, 1988.

Küng, H.: ¿Existe Dios?, Cristiandad, Madrid, 1979.

Küng, H.: Proyecto de una ética mundial, Trotta, 1991.

Küng; H.: El cristianismo. Esencia e historia, Trotta, 1997.

Lledó, E.: Memoria de la ética, Taurus, 1994.

López Aranguren, J. L.: Obras completas, Trotta, 1994-1997.

Martín Velasco, J.: Dios en la historia de las religiones, Fundación de Santa María, Madrid, 1895.

Mbiti, J.: Entre Dios y el tiempo. Religiones tradicionales africanas, ed. Mundo negro, Madrid, 1990.

Metz, J. B. y Wiesel, E.: Esperar a pesar de todo, Trotta, Madrid, 1996.

Muguerza, J. y Estrada, J. A.: Creencia e increencia: un debate en la frontera, Sal Terrae, 2000.

Muguerza, J.: Desde la perplejidad, FCE, México, 1995.

Muguerza, J., Quesada, F., Rodríquez Aramayo, R.: Ética día tras día, Trotta, 1991.

Neiman, S.: El mal en el pensamiento moderno, FCE, México, 2012.

Ohlig, K.H.: La evolución de la conciencia religiosa. La religión en la historia de la humanidad, Herder, 2004.

Onfray, M.: Tratado de ateología, Anagrama, 2008.

Otto, R. Lo santo, Círculo de Lectores, Madrid, 2000. Estudio introductorio de M. Fraijó.

Pannenberg, W. y otros, La revelación como historia, Sígueme, Salamanca, 1970.

Pannenberg, W.: Una historia de la filosofía desde la idea de Dios, Sígueme, 2002.

Pascal, B.: Pensamientos, Colección Austral (ed. Brunschvicg), Madrid, 1967.

Racionero Carmona, Q: «Lo sagrado y lo perfecto», en F. Duque (ed.), Lo santo y lo sagrado, Trotta, 1993, 77-138.

Reyes Mate, M.: Medianoche en la historia, Trotta, 2006.

Rodriguez Aramayo, R.: Crítica de la razón ucrónica, Tecnos, 1992.

Ricken, F.: Religionsphilosophie, W. Kohlhammer, Stuttgart, 2003.

Rorty, R., Vattimo, G.: El futuro de la religión, Paidós, Barcelona, 2006.

Sádaba, J.: De Dios a la nada, Espasa-Calpe, 2006.

Sádaba, J.: Lecciones de filosofía de la religión, Mondadori, 1989.

Safranski, R.: Un maestro de Alemania. Martin Heidegger y su tiempo, Tusquet, Barcelona.

Sánchez Bernal, J. J. (ed.): Anhelo de justicia. Teoría crítica y religión. Max Horkheimer, Trotta, 2000.

Sauter, G.: Zukunft und Verheissung, Theologischer Verlag Zürich, 1973 (2. ${ }^{a}$ ed.).

Savater, F.: La vida eterna, Ariel, Barcelona, 2007. 
Schleiermacher, F.: Sobre la religión. Discursos a menospreciadores cultivados, Tecnos, Madrid, 1990.

Stuart Mill, J.: La utilidad de la religión, Alianza, Madrid, 1986.

Torres Queiruga, A.: El problema de Dios en la modernidad, Evd, 1997.

Torres Queiruga, A.: Repensar el mal, Trotta, 2011.

Trías, E.: Pensar la religión, Ensayos/Destino, Barcelona, 1996.

Trías, E.: Por qué necesitamos la religión, Plaza \& Janés, 2000.

Tugendhat, E.: Antropología en vez de metafísica, Gedisa, 2008.

Valcárcel, A.: Ética para un mundo global, Temas de hoy, 2002.

Vattimo, G.: Después de la cristiandad, Paidós, 2003.

Unamuno, M.: Del sentimiento trágico de la vida, Espasa-Calpe, 1967.

Weischedel, W.: Der Gott der Philosophen, 2 vols. Deustscher Taschenbuch Verlag, Müchen, 1985. 